\title{
IN THE BEST INTERESTS OF THE CHILD?': AN INTERNATIONAL HUMAN RIGHTS ANALYSIS OF THE TREATMENT OF UNACCOMPANIED MINORS IN AUSTRALIA AND THE UNITED STATES
}

\author{
Emily A. Benfer*
}

\section{INTRODUCTION}

"[M] ankind owes to the child the best it has to give."2

A young boy in solitary confinement lay motionlessly on the concrete. ${ }^{3}$ His face was red, as though he had been crying. ${ }^{4}$ In order to walk, he had to be physically supported by guards. ${ }^{5}$ Horrified by being shackled and transferred to a high-security prison, he had not eaten for five days. ${ }^{6}$ The child ${ }^{7}$ was not allowed to make calls to an attorney and had no contact with the outside world. ${ }^{8}$ The warden finally alerted an attorney after the boy stopped breathing during an anxiety attack. ${ }^{9}$. When he saw the attorney, the young boy repeatedly begged: "Help me!"10 Once the attorney left, the boy was strip

1. Convention on the Rights of the Child, G.A. Res. 44/25, U.N. GAOR, 44th Sess., Supp. No. 49, Annex at 167, U.N. Doc. A/44/49 (1989); entered into force Sept. 2, 1990 [hereinafter CRC].

* J.D. Candidate, 2005, Indiana University School of Law - Indianapolis; B.A., 1999 , English, Writing, Providence College. To Professor Helen Grant, thank you for your guidance during the writing of this Note and for teaching me about the Australian legal system and Refugee-Asylum Law. To Lisa Koop, thank you for your assistance and for inspiring me through your endless dedication to ensuring the rights of migrant workers. This Note is dedicated to the thousands of children seeking refuge in countries not their own and suffering endless human rights violations as a result; may you find a safe haven and freedom from abuse.

2. Declaration of the Rights of the Child, G.A. Res. 1386, U.N. GAOR, 14th Sess., Supp. No. 16, at Preamble, U.N. Doc A/4359 (1959).

3. AMNESTY INTERNATIONAL, "WHY AM I HERE?" UNACCOMPANIED CHILDREN IN IMMIGRATION DETENTION 41 (2003), available at http://www.amnestyusa.org/refugee/ children_detention.html (last visited Mar. 13, 2004).

4. Id.

5. Id.

6. Id.

7. In this article, "child," "youth," "minor," and "juvenile" are used to describe a person under the age of eighteen.

8. AMNESTY INTERNATIONAL, supra note 3, at 41.

9. Id.

10. Id. 
searched ${ }^{11}$ and returned to a facility ${ }^{12}$ where he was shackled again and subject to punishment and isolation. ${ }^{13}$ The reason for the young boy's solitary confinement is unknown. ${ }^{14}$ One reason underlying his detention is clear: he was an unaccompanied minor who sought asylum in the United States. ${ }^{15}$

More than 100,000 children around the world flee from abuse and glaring human rights violations at any given time. ${ }^{16}$ When they arrive in a country perceived as a safe haven, these children are extremely vulnerable and are often suffering, emotionally and psychologically, from the trauma they experienced and from which they fled. ${ }^{17}$ Children escaping persecution have the right to seek asylum. ${ }^{18}$ International law establishes the best interests of the child as the highest priority and primary consideration in these types of asylum cases. ${ }^{19}$

Despite their internationally-declared rights, ${ }^{20}$ children seeking asylum in the United States and Australia are typically detained for an undetermined

11. Id. In the United States, detention centers report regularly subjecting unaccompanied minors to strip searches. See id. at 33-34. Juvenile offenders (people under 18 who have committed a crime) who are residents of the United States are exempt from strip searches in many detention facilities. See id.

12. Id. at 41 .

13. See Id. at 36.

14. AMNESTY INTERNATIONAL, supra note 3, at 41.

15. Id.

16. See UNITED NATIONS HIGH COMMISSIONER FOR REFUGEES (UNHCR), THE WORLD OF CHILDREN AT A GLANCE, at http://www.unhcr.ch/children/glance.html (last visited Mar. 13, 2004); See AMNESTY INTERNATIONAL, supra note 3, at 7. Refugees flee from risk of being "killed, raped, abducted, imprisoned, or tortured, often leaving behind everything they have." Id. Children are specifically vulnerable to human rights violations including "recruitment as child soldiers, child prostitution, child labor, slavery, trafficking, or abuses as street children." Id. WOMEN'S COMMISSION FOR REFUGEE WOMEN AND CHILDREN, PRISON GUARD OR PARENT?: INS TREATMENT OF UNACCOMPANIED REFUGEE CHILDREN 4 (2002) available at http://www. womenscommission.org/pdf/ins_det.pdf(last visited Mar. 13, 2004). See also AIlA's ASYLUM PRIMER: A PRACTICAL GUIDE TOU.S. ASYLUM LAW AND PROCEDURE 133 (Regina Germain ed., $3 \mathrm{~d}$ ed. 2003). "Children are victims of persecution and torture throughout the world. They are subjected to abusive child labor practices, are recruited by regular or irregular armies, are sold into prostitution or indentured servitude, and are subjected to various other human rights abuses." Id.

17. See Lisa Rodriguez Navarro, Comment, An Analysis of Treatment of Unaccompanied Immigrant and Refugee Children in INS Detention and Other Forms of Institutionalized Custody, 19 ChICANo-Latino L. REv. 589, 590 (1998). Fifty percent of children who flee suffer from post-traumatic stress disorder upon arrival in the United States. Id.

18. Universal Declaration of Human Rights, art. 14, G.A. Res. 217 (III), U.N. GAOR, 3d Sess., U.N. Doc. A/810 (1948) [hereinafter UDHR].

19. CRC, supra note 1 , art. 3.

20. See UDHR, supra note 18, art. 14. See also Convention Relating to the Status of Refugees, July 28, 1951, art. 31, 19 U.S.T. 6259, 6261, 189 U.N.T.S. 137, 152 [hereinafter Refugee Convention 1951]. See generally CRC, supra note 1. Only two countries in the world, the Unites States and Somalia-which has not had a government since 1991-are not signatories to the Convention on the Rights of the Child. See generally LAWRENCE J.LEBLANC, THE CONVENTION ON THE RIGHTS OF THE CHILD (1995). 
period until their immigration status is reviewed. ${ }^{21}$ This time period can extend into months or years. ${ }^{22}$ In 2001 , over 5,000 unaccompanied minors were detained in the United States, ${ }^{23}$ and over 1,100 children were detained in Australia. ${ }^{24}$ In detention, children face harsh conditions that affect their physical, ${ }^{25}$ mental, and emotional health. ${ }^{26}$ They are physically abused, ${ }^{27}$ sexually assaulted, ${ }^{28}$ and treated like prisoners. ${ }^{29}$

This Note seeks to analyze and critique the treatment of unaccompanied minors seeking asylum in the United States and Australia. Part II of this Note describes the current policies and legal doctrine in refugee and asylum law as they pertain to unaccompanied minors entering into, and already inside, the

21. AMNESTY INTERNATIONAL, supra note 3, at 1-2. In the United States, a child is detained until their immigration status is reviewed before the Executive Office of Immigration Review (EOIR). Id. In Australia, children are detained until their application for asylum is reviewed by the Department of Immigration and Multicultural and Indigenous Affairs (DIMIA). REFUGEE COUNCIL OF AUSTRALIA, ADVOCATE'S HELP KIT (2003), at http://www.refugeecouncil .org.au/html/resources/advocateskit.html\#howdo (last visited Mar. 13, 2004).

22. See AMNESTY INTERNATIONAL, supra note 3, at 1-2.

23. WOMEN's COMMISSION, supra note 16, at 1; Young Would-Be Refugees Find Harsh Fate Awaits in U.S., TORONTO STAR, Dec. 21, 2001, at A35. In 2001, 5,385 unaccompanied minors fled to the United States. See AMNESTY INTERNATIONAL, supra note 3, at 1 . Seventyfive percent of these children are boys and twenty-five percent are girls. See id. See also WOMEN's COMMISSION, supra note 16, at 1.

24. AMNESTY INTERNATIONAL AUSTRALIA, FACTSHEET 4: CHILDREN IN IMMIGRATION DETENTION IN AUSTRALIA (2003), at http://www.amnesty.org.au/refugees/ref-fact04.html (last visited Mar. 13, 2004).

25. See M.M. Suarez-Orozco, Everything you Ever Wanted to Know About Assimilation but Were Afraid to Ask, in ENGAGING IN CULTURAL DIFFERENCES: THE MULTICULTURAL ChaliEnge in Liberal Democracies 31 (R. Shweder, M. Minow \& H. Rose Markus eds., 1002). See also Jacqueline Bhabha, Children, Migration and International Norms in MIGRATION AND INTERNATIONAL LEGAL NORMS 203, 210 (Alexander Aleinikoff \& Vincint Chetail eds., TMC Asser Press 2003). See also Nikki Todd, Clinical Review Needed of Asylum Seekers, AAP NEWSFEED, May 8, 2002 (describing poor immunization levels and vitamin D deficiencies).

26. Todd, supra note 25. "Current practices of detention of infants and children are having immediate effects on their development and their psychological and emotional health which are likely to extend to the longer term." Id. "[C]hildren showing signs of deprivation and emotional neglect were "re-traumatized by the things that they witness or experience in detention.' Unaccompanied minors were particularly at risk," Dr. Louise Newman, the director of the NSW Institute of Psychiatry at Cumberland Hospital, Western Sydney, who was involved in a study that found "quite epidemic" levels of self-harm and suicide attempts, quoted in Larry Schwartz, No Respite For Child Detainees, SUNDAY AGE, Mar. 9, 2003, at 4. Totally Amazing Mind, So Understanding and So Kind; Prevalence of Mental Disorders, U.N. CHRONICLE, Mar. 22,1999 , at 24 (describing mental illness among unaccompanied minors).

27. See AMNESTY INTERNATIONAL, supra note 3, at 30.

28. Navarro, supra note 17, at 600 . See also Rob Taylor \& Joe Hildebrand, Govt Rebukes Human Rights Watchdog Over Child Detention, AAP NEWSFEED, Nov. 28, 2001 (describing how an allegation that a young boy was sold for sex in return for a cigarette in a detention center was dismissed).

29. See Navarro, supra note 17 , at 590. See also AMNESTY INTERNATIONAL, supra note 3 , at 28-38. 
United States and Australia. Part III describes the actual legal treatment of, or conditions faced by, unaccompanied minors in the United States and Australia. Part IV compares the practices in the United States and Australia to the international law and international agency recommendations which seek to guide the treatment of unaccompanied minors seeking asylum. The comparison reveals that the treatment of unaccompanied minors in both the United States and Australia violates international human rights law pertaining to children and should be redressed immediately. Finally, Part V provides recommendations to guide the United States and Australia in the process of making changes that are vital to the well-being of unaccompanied children fleeing dangerous situations.

\title{
II. LEGAL DOCTRINE AND PRACTICE GUIDING REFUGEE AND ASYLUM LAW IN THE TREATMENT OF UNACCOMPANIED MINORS
}

\section{A. The International Responsibility to Children Seeking Asylum}

\begin{abstract}
"All rivalries, all racial or religious antagonisms have vanished in the face of the agony of the children-who are the sacred heritage of the human race." 30
\end{abstract}

Historically, the recognition of children's rights was sporadic and oftentimes absent. ${ }^{31}$ It was not until 1924, when the League of Nations ${ }^{32}$ adopted the Declaration of the Rights of the Child ${ }^{33}$ that children were internationally recognized (even then, however, adversaries protested that children were not entitled to any rights at all). ${ }^{34}$ In 1989 , the Convention on the Rights of the Child (CRC) expanded international recognition of children's rights and

30. An appeal to the League of Nations prior to the adoption of the 1924 Declaration of the Rights of the Child. PAUL GORDON LAUREN, THE EVOLUTION OF HUMAN RIGHTS 119 (Bert Lockwood, Jr., ed., 1998) (quoting Societe des Nations, Document 20/48/160, "Intervention en faveur des enfants des pays eproves par la guerre," Dec. 2, 1920).

31. See Bhabha, supra note 25, at 203-04. In 1946 the Constitution of the International Refugee Organization included orphans under age sixteen as a category of refugees. Id. at 204 . In 1949, the Geneva Convention IV Relative to the Protection of Civilian Persons in Time of War asserted special treatment "in international armed conflicts to the wounded and sick, and to expectant mothers, but not to children" without specific circumstances. Id. at 204 . Children's entitlement to special treatment during armed conflict was recognized by the 1977 Geneva Protocol I. See id. at 205.

32. LAUREN, supra note 30, at 92-103. The League of Nations was created at the Paris Peace Conference of 1919 in response to the first World War. Id. U.S. President Woodrow Wilson, was instrumental in the development of the League of Nations and submitted the Draft Covenant which served as the basis for the League. $I d$. When the League failed to prevent the Second World War, it was replaced by the United Nations in 1942. See UNITED NATIONS, HISTORY OF THE UN, at http://www.un.org/aboutun/history.htm (last visited Mar. 13, 2004).

33. Bhabha, supra note 25, at 203-04.

34. LAUREN, supra note 30 , at $120,130$. 
became the most rapidly and widely adopted human rights treaty. ${ }^{35}$ The CRC was ratified by Australia in $1990 ;^{36}$ the United States signed the Convention in 1995 , but has yet to ratify it. ${ }^{37}$ Australia, as a ratifier, and the United States, as a signatory, are obligated to abide by the objectives and purposes of the treaty ${ }^{38}$ The CRC codified a child's right to special protection and required that the treatment of children promote the child's best interests. ${ }^{39}$ The CRC requires that "[n]o child shall be subjected to torture or other cruel, inhuman, or degrading treatment or punishment." 40 It also necessitates that a child's liberty be respected and restricted only if reasonably necessary. ${ }^{41}$

Detention of a child is only permitted "in conformity with the law ... as a last resort and for the shortest appropriate period of time." ${ }^{42}$ If a child is detained, the CRC requires that he or she be separated from adults, ${ }^{43}$ unless

35. CRC, supra note 1, art. 22(1) covers both children who have been granted refugee status and those seeking asylum. See Geraldine VAN BuEREN, THE INTERNATIONAL LAW ON THE RIGHTS OF THE CHILD 362 (1995).

36. AMNESTY INTERNATIONAL AUSTRALIA, FACTSHEET 11: AUSTRALIA's ObligationS (2003), available at $\mathrm{http}: / / \mathrm{www}$. amnesty.org.au/refugees.ref-fact1 1.html (last visited Mar. 13, 2004).

37. AMNESTY INTERNATIONAL, supra note 3, at 11. The United States and Australia were involved in the creation of Article 22 of the CRC. Considerations 1982 Working Group E/1982/12/Add.1, C, 64-68 in THE UNTTED NATIONS CONVENTION ON THE RIGHTS OF THE CHILD: A GUIDE TO THE “TRAVAUX PREPARATOIRES" 321 (Sharon Detrick ed., 1992)

The representative of Australia proposed the replacement in the first sentence of the words 'recognize that' by the words 'shall ensure that'; he also proposed that the words 'needs special protection and assistance' at the end of the first sentence and the whole of the second sentence should be replaced by 'receives adequate protection and assistance in the enjoyment of the rights contained in this Convention' .... . The delegation of the United States suggested the addition of the words 'and in the best interests of the child' to the words 'where appropriate.'

Id.

38. Vienna Convention on the Law of Treaties, May 23, 1969, art. 18, 1155 U.N.T.S. 331. See also AMNESTY INTERNATIONAL, supra note 3, at 11.

39. VAN BUEREN, supra note 35, at 205. CRC, supra note 1, art. 3(1). See also UDHR, supra note 18 , art. 5 .

40. CRC, supra note 1, art. 37(a). See also UDHR, supra note 18, art. 9.

41. CRC, supra note 1 , art. 37(b).

42. Id. Any person who is detained internationally has the right to be notified of their rights and the reason for their detention. Body of Principles for the Protection of All Persons Under Any Form of Detention or Imprisonment, prin. 11, G.A. Res. 43/173, U.N. GAOR, 43d Sess., Annex, Supp. No. 49, at 298, U.N. Doc. A/43/49 (1988); International Covenant on Civil and Political Rights, opened for signature Dec. 19, 1966, art. 14, 999 U.N.T.S. 172, 175, 177 (entered into force Mar. 23, 1976) reprinted in INTERNATIONAL DOCUMENTS ON CHILDREN (Geraldine Van Bueren, ed., 1993) [hereinafter ICCPR]. The ICCPR was ratified by the United States in 1992 and Australia in 1993. Id. However, the United States reserves the right to only abide by the ICCPR where it is consistent with domestic law. AMNESTY INTERNATIONAL, supra note 3 , at 9 .

43. $\mathrm{CRC}$, supra note 1 , art. 37 (c). International law requires that juvenile offenders also be separated from adults. ICCPR, supra note 42, art. 10(2) (b). "Accused juvenile persons shall be separated from adults and brought as speedily as possible for adjudication." Id. See also American Convention on Human Rights, Nov. 22, 1969, art. 5(5), Series no. 36, at 1, 
the best interest of the child necessitates otherwise. ${ }^{44}$ In the event a child is deprived of his or her liberty, the CRC requires that the child be "treated with humanity and respect for the inherent dignity of the human person, and in a manner which takes into account the needs of persons his or her age."45 A child who is detained has the right of "prompt access" to legal assistance and the right to challenge the legality of his or her detention in front of an "independent and impartial authority." ${ }^{46}$ Furthermore, he or she has the right to consular notification and access. ${ }^{47}$

The Universal Declaration of Human Rights (UDHR) provides everyone with "the right to education" 48 which is granted "on the basis of equal opportunity." 49 Equal opportunity requires that children be accommodated according to their language and economic background. ${ }^{50}$ Children also have the right to exercise religious and moral beliefs which must be respected by all governments. ${ }^{51}$

The UN describes the prolonged detention of unaccompanied minors as "not only inhumane but illegal."s2 Articles Three and Nine of the 1948

Organization of American States, Official Record, OEA/Ser.L/V/II.23 (entered into force July 18,1978 ) [hereinafter American Convention]. "Minors while subject to criminal proceedings shall be separated from adults and brought before specialized tribunals, as speedily as possible, so that they may be treated in accordance with their status as minors." Id.

44. See Bhabha, supra note 25 , at $212-16$. In situations where the child is accompanied by an adult, parent or legal guardian, they have the right not to be separated from them. Id.

45. See generally CRC, supra note 1 . See also ICCPR, supra note 42, art. 39.

46. CRC, supra note 1 , art. 37(d). The child has the right to a "prompt decision in any such action." Id.

47. Bhabha, supra note 25, at 208; Vienna Convention on Consular Relations, Apr. 24, 1963, art. 36, 21 U.S.T. 77, 596 U.N.T.S. 261, available at http://www.courtinfo.ca.gov/ programs/courtinterpreters/ documents/vienna.pdf (last visited Mar. 13, 2004).

48. UDHR, supra note 18, art. 26(1). See generally VAN BUEREN, supra note 35, at 23261. Only primary education is compulsory, though secondary education and special education for handicapped people are recommended. CRC, supra note 1, art. 28(1). See also International Covenant on Economic, Social and Cultural Rights, art. 13, opened for signature Dec. 16, 1966, 993 U.N.T.S. 3, (entered into force on Jan. 3, 1976 [hereinafter ICESCR]; Refugee Convention 1951, supra note 20, art. 22; European Convention on Human Rights, Prot. 1, art. 2, 213 U.N.T.S. 221 [hereinafter ECHR]; Additional Protocol to the American Convention on Human Rights in the Area of Economic, Social and Cultural Rights, "Protocol of San Salvador," adopted Nov. 17, 1988, art. 13(3)(a)(b)(e), O.A.S. Treaty Series 69, reprinted in INTERNATIONAL DOCUMENTS ON CHIIDREN, supra note 42, at 73. Although the United States is not a party to these treaties, it has recognized the right of children, even undocumented and noncitizen children, to free primary education. See generally Plyler v. Doe, 457 U.S. 202 (1981).

49. CRC, supra note 1 , art. 28(1).

50. Bhabha, supra note 25, at 210 . See also INTERNATIONAL DOCUMENTS ON CHILDREN supra note 42; Convention Against Discrimination in Education, Dec. 14, 1960, art. 3(e), 429 U.N.T.S. 93, available at http://www.unesco.org/education/pdf/DISCRI_E.PDF (last visited Mar. 13, 2004) (granting equal access to education to children who are resident and foreign nationals).

51. Bhabha, supra note 25, at 210; VAN BEUREN, supra note 35, at 32-38.

52. Commission on Human Rights, Migrant Workers, Report of the Special Rapporteur, Ms. Gabriela Rodríguez Pizarro, U.N. Doc. E/CN.4/2001/83/Add.1 (2001). 
Universal Declaration of Human Rights protect everyone from arbitrary arrest and detention. ${ }^{53}$ The International Covenant on Civil and Political Rights (ICCPR) regards unnecessary detention as a violation of the rights to liberty and security of person. ${ }^{54}$ Accordingly, separated children ${ }^{55}$ and unaccompanied minors should not be detained. ${ }^{56}$ Only certain circumstances necessitate initial detention. ${ }^{57}$ For example, establishing a person's identity or performing health and security checks may justify short-term detention. ${ }^{58}$ In addition, juvenile offenders - children alleged to have committed or who have been found to have committed an offense or who pose a threat to themselves or society - may be detained as a last resort. ${ }^{59}$ Although it may be necessary to detain a child when he or she poses a risk to public safety, this Note is premised on situations where the unaccompanied minor is not a threat. International human rights law forbids detaining people beyond a reasonable length of time if they do not threaten national security. ${ }^{60}$

53. UDHR, supra note 18, art. 3, art. 9. Detention "does not, per se, violate the prohibition on arbitrary arrest and detention; however, such detention must conform with domestic law and be reasonable in length." Bhabha, supra note 25, at 211. See also ICCPR, supra note 42, art. 9; European Convention Human Rights, art. S(1) (f) (1950) available at http://www.hri.org/docs/ECHR50.html (last visited Mar. 13, 2004); A. v. Australia, CCPR/C/59/D/560/1993 (Human Rights Committee, Apr. 30, 1997) (holding that prolonged detention without evidence of necessity may violate the principle of proportionality).

54. ICCPR, supra note 42, art. 9.1, 9.4.

55. Separated children are those children who are divided from their parents or legal guardian and outside their country of origin; these children may be alone, with extended family, or with an adult (some are being trafficked, labored, or subjected to another form of force). See S. RUXTON, SEPARATED CHILDREN SEEKING ASYLUM IN EUROPE: A PROGRAMME FOR ACTION (2000). In the event a child arrives in a country with his or her family, the child has the right not to be separated from the family. Bhabha, supra note 25, at 212-16.

56. UNHCR, Guidelines on Policies and Procedures in Dealing with Unaccompanied Children Seeking Asylum $\$ 7.6$ (Feb. 1997), available at http://www.unhcr.ch/cgi-bin/texis/ vtx/home/opendoc.pdf?tbl=MEDIA\&id=3d4f9l cf4\&page=publ (last visited Mar. 13, 2004) [hereinafter Guidelines on Policies].

57. AMNESTY INTERNATIONAL AUSTRALIA, FACTSHEET 9: MANDATORY DETENTION OF ASYLUM SEEKERS (2003), at http://www.amnesty.org.au/refugees/ref-fact09.html (last visited Mar. 13, 2004).

58. $1 d$.

59. United Nations Standard Minimum Rules for the Administration of Juvenile Justice ("The Beijing Rules"), G.A. Res. 40/33, U.N. GAOR, 40th Sess., Annex, Supp. No. 53, at 207 U.N. Doc. A 40/53 (1985) reprinted in INTERNATIONAL DOCUMENTS ON CHILDREN supra note 42, at 200 [hereinafter The Beijing Rules].

60. FACTSHEET 9, supra note 57. 
International human rights documents,${ }^{61}$ such as the Universal Declaration of Human Rights (UDHR) and the United Nations Convention Relating to the Status of Refugees (1951 Refugee Convention), apply to children ${ }^{62}$ unless expressly stating the contrary. ${ }^{63}$ Thus, the UDHR applies to "everyone ... without distinction of any kind." 64 It grants "everyone ... the right to seek and enjoy asylum from persecution." 65 The UDHR also specifically enumerates a child's entitlement to "special care and assistance." 66 The 1951 Refugee Convention provides that no one should be returned to a country where he or she faces serious human rights violations. It also offers protection to all who meet its requirements. ${ }^{67}$ The international laws and guidelines,

61. In addition to international law, the international community has adopted non-treaty standards that provide guidelines and have authoritative force. See generally UNHCR, Revised Guidelines on Applicable Criteria and Standards Relating to the Detention of Asylum Seekers, (Feb. 1999); UNHCR, Refugee Children: Guidelines on Protection and Care, (1994) available at http://www.unhcr.ch/cgi-bin/texis/vtx/protect (last visited Mar. 13, 2004) [hereinafter Guidelines on Protection and Care]; Guidelines on Policies supra note 56; United Nations Rules for the Protection of Juveniles Deprived of Their Liberty, G.A. Res. 45/113, U.N. GAOR, 45th Sess., Annex, Supp. No. 49A, at 205, U.N. Doc A/45/49 (1990) [hereinafter Protection of Juveniles]; The Beijing Rules, supra note 59; Basic Principles for the Treatment of Prisoners, G.A. Res. 45/111, U.N. GAOR 45th Sess., Annex, Supp. No. 49A, at 200, U.N. Doc. A/45/49 (1990); Standard Minimum Rules for Treatment of Prisoners, Aug. 30, 1955, Annex I, at 67, U.N. Doc. A/CONF/6/1 (1956), adopted by E.S.C. Res. 663 (XXIV) C, U.N. ESCOR, 24th Sess., Supp. No. 1, at 11, U.N. Doc. E/3048 (1957).

62. Bhabha, supra note 25, at 205. See UNHCR Exec. Comm., Refugee Children, para. (u), No. 47 (XXXVIII)(1987), available at http://www.unhcr.ch/cgi-bin/texis/vtx/excom (last visited Mar. 13, 2004); Guidelines on Protection and Care, supra note 61, at chp. III; UNHCR, Guidelines on Policies supra note 56, at 1-21. See also UNHCR, Handbook on Procedures and Criteria for Determining Refugee Status under the 1951 Convention; Protocol Relating to the Status of Refugees, Jan. 31, 1967, para. 213-19, U.N. doc. HCR/IP/4/Eng/Rev.1, 606 U.N.T.S. 267. 268 (text dedicated to unaccompanied minors) [hereinafter 1967 Protocol]; UNHCR Exec. Comm., General Conclusion on International Protection, para. (m), conclusion 47, 91, No. 41 (XXXVII) (1986), available at http://www.unhcr.ch/cgi-bin/texis/vtx/excom (last visited Mar. $13,2004)$.

63. See Bhabha, supra note 25 , at 205 . "All children have fundamental human rights, including the right to due process and to be treated humanely." AMNESTY INTERNATIONAL, supra note 3 , at 7 .

64. LAUREN, supra note 30 , at 248.

65. UDHR, supra note 18 , art. 14.

66. Id. art. 25, § 2. See also ICESCR, supra note 48. "Special measures of protection and assistance should be taken on behalf of all children and young persons without any discrimination for reasons of parentage or other conditions." Id.

67. AMNESTY INTERNATIONAL, supra note 3, at 7-8 (citing Refugee Convention 1951, supra note 20). Although the United States was involved in the creation of refugee rights and in 1980 brought its laws in line with the 1967 Protocol, it reduced protection in the Illegal Immigration Reform and Immigrant Responsibility Act of 1996. Id. See also 1967 Protocol, supra note 62. The concept of non-refoulement is highlighted by Article 33 of the 1951 Convention: "No Contracting State shall expel or return ("refouler") a refugee in any manner whatsoever to the frontiers of territories where his [or her] life or freedom would be threatened

." Refugee Convention 1951, supra note 20, at art. 33. See also KAREN MUSALO ET AL., REFUGEE LAW AND POLICY: A COMPARATIVE AND INTERNATIONAL APPROACH 40, 57-146 (2002). "There is no lower age limit to the well-established international right to claim asylum 
which recognize children as deserving of special status and treatment, are derived from the knowledge that children are especially vulnerable due to their nascent stage of development and their dependency on adults for their well-being. ${ }^{68}$

\section{B. The Legal and Procedural Response to Unaccompanied Minors Seeking} Asylum in the United States

"Children have a very special place in life which [the] law should reflect." 69

On March 1, 2003, the responsibility for immigration-related services in the United States, including asylum, was transferred from the Immigration and Naturalization Service (INS) to the Bureau of Citizenship and Immigration Services (BCIS) in the Department of Homeland Security (DHS).$^{70}$ The Secretary of Homeland Security delegated to BCIS the discretionary authority to admit any "refugee who is not firmly resettled in a third country, who is determined to be of special humanitarian concern, and who is admissible as an immigrant." of 2002 and gave the Office of Refugee Resettlement (ORR) responsibility for the provision of care for unaccompanied immigrant minors. ${ }^{72}$ The responsibilities of the ORR include making placement decisions, identifying sufficient qualified placements to house unaccompanied minors, developing a plan to ensure the appointment of counsel, and conducting investigations of facilities

or resist refoulement to a persecuting or torturing country." Bhabha, supra note 25 , at 211 (citing UDHR, supra note 18, art. 14, Refugee Convention 1951, supra note 20, art. 32, 33). See also ICCPR, supra note 42, art. 13; Convention Against Torture and Other Cruel, Inhuman or Degrading Treatment or Punishment, adopted Dec. 10, 1984, art. 3, G.A. Res. 39/46, U.N. GAOR 39th Sess., Supp. No. 51, at 197, U.N. Doc. A/39/51 (1984) (entered into force 26 June 1987); ECHR, supra note 48, art. 3, 213 U.N.T.S. 221. See also Cartagena Declaration on Refugees, Inter-Am. C.H.R, OAS/Ser.L/V/II.66, doc. 10, rev. 1 (1984) reprinted in 2 UNHCR, Collection of International Instruments and Other Legal Texts Concerning Refugees and Displaced Persons: Regional Instruments 206, UN Sales No. GV. E. 96.0 .2 (1995).

68. AMNESTY INTERNATIONAL, supra note 3, at 11. See A. GLENN MOWER, JR., THE CONVENTION ON THE RIGHTS OF THE CHILD: INTERNATIONAL LAW SUPPORT FOR CHILDREN 3 (1997); CRC, supra note 1, Preamble.

69. May v. Anderson, 345 U.S. 528, 536 (1953) (Frankfurter, J., concurring).

70. U.S. DEPARTMENT OF HOMELAND SECURITY, available at http://www.dhs.gov/ dhspublic/theme_home4.jsp (last visited Mar. 13, 2004).

71. BUREAU OF CITIZENSHIP AND IMMIGRATION SERVICES (BCIS), USCIS AUTHORITY IN REFUGEE PROCESSING, at http://uscis.gov/graphics/services/refugees/INSAuthority.htm (last visited Mar. 13, 2004).

72. Homeland Security Act of 2002, Pub. L. No. 107-296, 116 Stat. $2135 \S 462$ (Nov. 25, 2002). 45 F.R. Part 400, Subpart H Child Welfare Services; Immigration and Nationality Act (INA) 8 U.S.C. $\$ 412$ (a)(6) [hereinafter INA]; INA § 412 (d)(2)(A); INA § 412 (d)(2)(B); Title $\mathrm{V}$ of the Refugee Education Assistance Act of 1980. See 8 Members of Congress Urge Release of Immigrant, N.Y. TIMES, Aug. 23, 2003, at A9. 
housing unaccompanied minors. ${ }^{73}$ This shift in responsibility marked a positive step from hostility toward children as "unpredictable illegal aliens," who should be deported under the recent homeland security perspective, to concern for them as "particularly vulnerable migrants" needing guardians. ${ }^{74}$ Although the transfer to ORR signals an improvement, the treatment of unaccompanied minors in the United States still does not conform to international human rights law. ${ }^{75}$ This failure is discussed in greater depth in Part IV.

In practice, immigration officials initiate a "removal proceeding" for nearly all unaccompanied minors who arrive at the U.S. border without documentation. ${ }^{76}$ While children await their removal proceeding, they are usually detained $;{ }^{77}$ the average period of detention is 34.2 days. ${ }^{78}$ However, children have been held for months or even years. ${ }^{79}$ In order to avoid deportation, children must raise a defense ${ }^{80}$ which, under limited circumstances, may include applying for asylum ${ }^{81}$ or for status as a victim of torture, abuse, neglect, ${ }^{82}$ trafficking, ${ }^{83}$ and other crimes committed against them. ${ }^{84}$ An unaccompanied minor or child at risk may obtain Special Immigrant Juvenile status if he or she has been a victim of abuse, abandonment, neglect, or domestic violence. ${ }^{85}$ Additionally, unaccompanied minors who are victims of trafficking or child abuse may receive protection under the Victims of Trafficking and Violence Protection Act (2000) ${ }^{86}$ If unaccompanied children

73. Letter from Nguyen Van Hanh, Ph.D., Director Office of Refugee Resettlement, to State Refugee Coordinators (Jan. 29, 2003), at http://www.acf.dhhs.gov/programs/orr/policy/ sl03-01 att.htm (last visited Mar. 13, 2004) [hereinafter Letter].

74. J. Bhabha, Minors or Aliens? Inconsistent State Intervention and Separated Child Asylum-Seekers, 3 EUR. J. MIGRATION L. 299-324 (2001).

75. Bhabha, supra note 25 , at 211.

76. AMNESTY INTERNATIONAL, supra note 3, at 12; INA, 8 C.F.R. § 212 (1952)

77. Letter, supra note 73. The Immigration and Nationality Act (INA) mandates detention of people entering the United States without necessary documentation. INA supra note 72, $\S 236.3 ; 8$ U.S.C. $\S 1226$.

78. Letter, supra note 73.

79. Young Would-Be Refugees, supra note 23 . The average time in custody is forty days. Id. However, in Mohamed Boukrage's not uncommon case, the sixteen year-old was detained for over two years. Id.

80. Id.

81. INA, supra note $72, \S 101(\mathrm{a})(42)$.

82. Id., § 101(a)(27)(J).

83. Victims of Trafficking and Violence Protection Act, Pub. L. No. 106-396, 114 Stat. $1464(2000)$ [hereinafter Victims]. Victims must show that they would be subjected to severe harm if deported. Id.

84. See id. See also C. Nugent \& R. Schulman, Giving Voice to the Vulnerable: On Representing Detained Immigrant and Refugee Children, 78 INTERPRETER RELEASES (2001) at 1569. Less than fifty percent of unaccompanied minors receive the assistance of counsel. Id.

85. INA, supra note $72, \S 101$ (a)(27)(J). Eligible minors receive permanent citizenship status. Id.

86. Victims, supra note 83. 
gain refugee status, the Office of Refugee Resettlement (ORR) assists them in resettling. ${ }^{87}$

The detention policy codified in the Immigration and Nationality Act (INA) requires that minors may only be released from detention to their parents, close relatives, or legal guardians. ${ }^{88}$ However, if parents come forward and are themselves illegally in the United States, they risk immediate detention. ${ }^{89}$ In Reno v. Flores, the U.S. Supreme Court held that limiting release to non-family members in only unusual and compelling circumstances did not violate the immigrant minors' procedural due process and was not unreasonable. ${ }^{90}$ Following the law suit, a settlement agreement, known as the Flores guidelines, created nationwide obligations that pertain to the detention and release of children in immigration custody. ${ }^{91}$ The obligations are based on the premise that children must be treated with "dignity, respect, and special concern for their vulnerability as minors." 92 Regretfully, the Flores guidelines were never implemented. ${ }^{93}$ Coupled with international law, however, these guidelines provide the standard against which the U.S. treatment of unaccompanied minors may be compared. ${ }^{94}$

On May 22, 2003, the Unaccompanied Alien Child Protection Act of 2003 was introduced by U.S. Senator Dianne Feinstein in the Senate and referred to the Committee on the Judiciary. ${ }^{95}$ This bill is sponsored by eighteen senators and responds to the shortcomings of immigration law as it

87. U.S. DEPARTMENT OF HEATH \& Human SERVICES, OfFice OF Refugee ResetTlement (ORR), The UnACCOMPANiEd Refugee MinORS PROGRAM, at http://www.acf.dhhs.gov/programs/orr/programs/urm.htm(last visited Mar. 13, 2004). Services provided by the ORR include English language tutoring, career planning, physical and mental health care, family reunification, residential placement and Ethnic and religious preservation. Id.

88. 8 C.F.R. \& 236.3 (2002).

89. MUSALO ET AL., supra note 67 , at 808.

90. Reno v. Flores, 507 U.S. 292 (1993). See also MUSALO ET AL., supra note 67, at 808; Daniel D'Angelo, Reno v. Flores: What Rights Should Detained Alien Juveniles Be Afforded?, 21 N.E. J. CRIM. \& CIV. CON. 463 (1995). See also Gail Quick Goeke, Substantive and Procedural Due Process for Unaccompanied Alien Juveniles, 60 Mo. L. REv. 221 (1995); Michael C. Ranalli, Reno v. Flores: Plenary Power Over Immigration Alive and Well, 45 MERCER L. REV. 889 (1994).

91. AMNESTY INTERNATIONAL, supra note 3, at 16 (citing Flores v. Reno, Case No. CV85-4544-RJK (C.D. Cal.1996) 75 Interpreter Releases 1020 (July 27, 1998)).

92. Id. Obligations include

(1) ensure the prompt release of children from immigration detention; (2) place children for whom release is pending, or for whom no release option is available, in the 'least restrictive' setting appropriate to the age and special needs of minors; and (3) implement standards relating to care and treatment of children in U.S. immigration detention.

Id. The Flores standards have expired and were not incorporated into INS regulations. See id.

93. AMNESTY INTERNATIONAL, supra note 3, at 17.

94. Id.

95. Unaccompanied Alien Child Protection Act of 2003, S. 1129, 108th Cong. (2003) [hereinafter UACP]. 
pertains to unaccompanied minors, discussed in Part III. The bill sets forth procedures for immigration officers who find unaccompanied minors entering the United States. ${ }^{96}$ It provides that care of unaccompanied minors who have not been convicted of a felony are the responsibility of the ORR. ${ }^{97}$ Furthermore, it prohibits the detention of minors with adults or in facilities for juvenile offenders, and mandates the provision of counsel. ${ }^{98}$ At the time this Note was written, government representatives had yet to oppose the Unaccompanied Alien Child Protection Act of 2003. ${ }^{99}$ However, the likelihood of passage is only twenty-two percent in the Senate Committee and one percent in the House Committee. ${ }^{100}$ If this proposed legislation, sponsored by eighteen senators, is enacted, it would greatly improve the treatment of minors in the United States and align the United States with international law and policy pertaining to unaccompanied minors.

\section{The Legal and Procedural Response to Unaccompanied Minors Seeking Asylum in Australia}

"This is a local problem and we can address it our own way, but I won't have any bleeding heart or anybody else telling us what to do."101

Australia is the only Western country with a mandatory detention policy for all undocumented immigrants. ${ }^{102}$ The Australian Migration Act of 1958 provides that an "unlawful non-citizen" must be kept in "immigration detention" until deported or granted a visa. ${ }^{103}$ The Immigration Minister, under the Migration Act, has the authority to designate Immigration Detention Centers. ${ }^{104}$ Detention Centers are the standard; alternative custody arrange-

96. Id. at Summary.

97. See id.

98. See id.

99. E-mail from Megan McKenna, Media Liaison, Women's Commission for Refugee Women and Children, to Emily Benfer, J.D. Candidate 2005 (Nov. 14, 2003, 09:25 CST) (on file with author).

100. See S. 1129 Billcast, 108th Congress (2003-2004) at http://www.westlaw.com (last visited Mar. 13, 2004).

101. Australian Mayor Joy Baluch quoted in Mark Phillips, Asylum Policy Softer, HERALD Sun, Dec. 3, 2002, at 15.

102. Alexander J. Wood, The "Pacific Solution": Refugees Unwelcome in Australia, 9 HUM. RTS. BR. 22 (2002); UNICEF Demands Children be Released From Detention, AAP NEWSFEED, June 6, 2002; Pam O'Toole, Analysis: Australia's Tough Asylum Policy, BBC, Jan. 24, 2002; P. Barkham, No Waltzing in Woomera, THE GuARDIAN, May 25, 2002, at 24.

103. Savitri Taylor, Protecting the Human Rights of Immigration Detainees in Australia: An Evaluation of Current Accountability Mechanisms, 22 SYDNEY L. REV. 50, 51 (2000). An unlawful non-citizen is a person who is present in Australia and is not a citizen and does not hold a visa. Id.

104. See Id., at 52. See also, id. at 52, n. 7. 
ments have seldom been established and only in response to pressure from the Commonwealth. ${ }^{105}$ For example, in 2002, guidelines under which unaccompanied minors would be placed in foster care as an alternative to high-security detention centers produced only a $0.4 \%$ decrease in the number of children in detention. ${ }^{106}$ The Immigration Act of 1946 makes the Minister for Immigration and Multicultural and Indigenous Affairs both the guardian of children and the person responsible for removing them from the country. ${ }^{107}$ The Minister's dual role presents a conflict of interest because the child's welfare may not always be a priority. ${ }^{108}$

The Department of Immigration and Multicultural and Indigenous Affairs (DIMIA) outsourced management of detention centers to Australian Correctional Services (ACS). ${ }^{109}$ ACS is responsible for providing guards, translators, meal services, cleaning services, education, health care, escort and transportation services in addition to "any other services necessary to enable delivery of Detention Services in accordance with the Immigration Detention Standards." 110 In the event services are not satisfactory, provisions are in place for detainees to complain directly to DIMIA. ${ }^{11}$ However, detainees are typically afraid that their visa status will be affected or their time in detention made harder and are often unwilling to report the details of their treatment. ${ }^{112}$

The High Court in Australia is currently deciding the legality of indefinitely detaining children. ${ }^{113}$ Five children who had been in detention for thirty-two months were released from detention on August 25, 2003, after the Family Court found that prolonged detention placed the children's health at risk. ${ }^{114}$ The Family Court decided that the indefinite detention of child asylum

105. See id.

106. Larry Schwartz, supra note 26.

107. X v. Minister for Immigration and Multicultural Affairs, Federal Court of Australia FCA995 (July 23, 1999). The court found that there is no requirement for the appointment of a tutor in cases against the minor's guardian, the Minister. See id.

108. ChILOUT, ThE HEART OF THE NATION's EXISTENCE 140 (2002) available at http://www.chilout.org (last visited Mar. 13, 2004). In an appeal from the Family Court which held that continued detention of children was unlawful, the government argued that UN Convention on the Rights of the Child was irrelevant to the detention of children. See Minister for Immigration and Multicultural and Indigenous Affairs v. B (Infants) and B (Intervener) (2003) 30 Fam LR 251.

109. Taylor, supra note 103 , at 54. Australian Correctional Services is a partnership between Australian Correctional Management and Thiess Contractors Pty. Ltd. Id.

110. Taylor, supra note 103 , at 54.

111. See id. at 57.

112. See id.

113. See generally Minister for Immigration and Multicultural and Indigenous Affairs v. B \& Anor (2003) A246.; Cynthia Banham, Battle Over Child Detention Policy Goes to High Court, SYDNEY MORNING HERALD, Oct. 1, 2003.

114. See generally B (Infants) \& B (Interveners) v. Minister for Immigration and Multicultural and Indigenous Affairs (2003) 30 Fam.C.A. 181; Meaghan Shaw, High Court Invites Child Detention Pleas, AGE, Oct. 1, 2003. 
seekers is illegal. ${ }^{115}$ The government appealed the case, arguing that international law, like the CRC, does not apply, and only the Migration Act is binding. ${ }^{16}$ Frustrated that the case was before the court on appeal rather than as a direct challenge to the constitutionality of it, the High Court invited refugee lawyers to file a case to challenge the legality of detaining minors. ${ }^{117}$ During the writing of this Note, the High Court adjourned a preliminary hearing and had yet to publicize its ruling. ${ }^{118}$ If the High Court upholds the decision of the Family Court, it might result in the reformation of Australia's mandatory detention policy.

\section{THE TREATMENT OF UNACCOMPANIED MINORS AND THE EFFECTS OF DETENTION ON CHILDREN}

\section{A. The Experience of the Unaccompanied Minor Seeking Asylum in the United States}

When a child's life or liberty or innocence is taken, it is a terrible, terrible loss. And those responsible have committed a terrible crime. Our society has a duty, has a solemn duty, to shield children from exploitation and danger.... Our first duty as adults is to create an environment in which children can grow and thrive without fearing for their security. That's what we've got to do. Because children are so vulnerable, they need the care of adults. Because they're so vulnerable, those who are cruel and predatory often target our children.

\section{See id.}

116. Banham, supra note 113. Immigration Minister Philip Ruddock said, "What we have is the courts saying, 'We don't care that there's a public policy way in which these matters are properly looked at. We're going to impose our views . . . Now I think that's in excess of the Family Court's jurisdiction . . . That's why I'm appealing the Family Court's decision." Ruddock Says Refugee Policy Has Saved Many Lives, AAP NEwSFEED, Aug. 26, 2003. The government's appeal of the Family Court decision to release the children from detention was met with shock: "The cold-hearted actions by this minister continue to astound us ... The fact that he is unable to accept a decision by a court that specializes in the welfare of children shows that he just does not care," said Senator Andrew Bartlett, who leads the Australian Democratic party. Court Rules that Locking Children in Refugee Detention Camps is Illegal, AP WORLD NEWS, June 19, 2003, available at http://www.unhcr.ch/cgi-bin/texis/vtx/print?tbl=NEWS\& id=3ef2c4934 (last visited Mar. 13, 2004). Philip Ruddock, the Immigration Minister, was recently appointed to Attorney General of Australia. Cynthia Banham, The Law Unto Himself, SYDNEY MORNING HERALD, Oct. 7, 2003, at 14.

117. Shaw, supra note 114.

118. High Court Adjourns Child Detention Hearing, ABC VICTORIA, Oct. 31, 2003, at Local News. The hearing is tentatively scheduled for February 2004. Dan Silkstone, Detentions Challenge Can Proceed, AGE, Nov. 20, 2003, at 9. 
... All these dangers put children at risk. All these dangers demand action to protect our children from harm. ${ }^{119}$

Children are especially vulnerable to abuse and are often exploited by virtue of their youthfulness and naivete. ${ }^{120}$ Oftentimes, unaccompanied minors have already suffered from harm and abuse. ${ }^{121}$ Minors arrive in the United States unaccompanied for multiple reasons, including, but not limited to, separation from their guardian, flight from abuse, for survival, or because their families-hoping to give them safety-have sent them ahead. ${ }^{122}$ Regardless of why they arrived illegally and alone, children, of all the people seeking refuge in the United States, are the most in need of careful individual attention. ${ }^{123}$ Despite the urgent need, states' practice toward children is "more generous in relation to expulsion than it is in relation to admission." ${ }^{24}$ For example, the United States accepted only one unaccompanied minor for resettlement in 1997 and only eleven in $1998 .{ }^{125}$

119. AMNESTY INTERNATIONAL, supra note 3, at 15-16 (quoting President George W. Bush, Remarks at White House Conference on Missing, Exploited, and Runaway Children, Ronald Regan Building, Washington, D.C., October 2002).

120. See id. See also MOWER, supra note 68 , at 42 . Children are often victims of people smuggling and trafficking. Bhabha, supra note 25 , at 219; G. Thompson, Guatemala Intercepts 49 Children Illegally Bound for U.S., N.Y. TIMES, Apr. 8, 2002, at A2; D.M. Halbfinder, Three Charged with Running Mexican Baby-Smuggling Ring, N.Y. TIMES, May 28, 1999, at A1; On the Fence: Former INS Commissioner Doris Meissner on the Contradictions of Migration Policy in a Globalizing World, CARNEGIE ENDOWMENT FOR INT'L PEACE FOREIGN POL'Y, Mar. 1,2002 , at 23. For more information about children recruited or forced to become soldiers, see Bhabha, supra note 25 , at 218 . For more information about the sexual, economic and other exploitations of children, see VAN BUEREN, supra note 35, at $262-86$.

121. AMNESTY INTERNATIONAL, supra note 3, at 7.

122. Michael A. Olivas, Unaccompanied Refugee Children: Detention, Due Process, and Disgrace, 2 STAN. L. \& POL'Y REV. 159, 160 (1990). Immigrant minors usually arrive in the U.S. unaccompanied because they "either fled their country without adults, were sent ahead by family members in hope that they would emigrate more safely, or become accidentally separated from adults during flight." Id.

123. AMNESTY INTERNATIONAL, supra note 3, at 7; Bhabha, supra note 25, at 203; CRC, supra note 1, Preamble.

124. Bhabha, supra note 25, at 207.

125. Prepared Testimony of Nicholas A. Dimarzio Bishop of Camden Chairman National Conference of Catholic Bishops' Committee on Migration Before the Senate Judiciary Committee Subcommittee on Immigration, FED. NEWS SERVICE, Aug. 4, 1999 [hereinafter Prepared Testimony of Nicholas A. DimarzIO]

. In 2000, Elian Gonzales received exceptional treatment which is not the norm. See Natalie Allen, Attorney General Reno Holds News Conference on Elian Gonzalez Court Decision, CNN Breaking News, June 1, 2000; Battle Over Elian Plays Out in Front of Cameras Amid Questions About Methods and Motives, CNN, Apr. 23, 2000. With the publicity surrounding the Gonzales case, the public concern for unaccompanied minors increased and resulted in congressional moves to change policy. See Unaccompanied Alien Child Protection Act of 2001, S. 121 107th Cong. (2001); H.R. 1904, 107th Cong. (2001). The Bill has yet to be passed. See UACP, supra note 95. 


\section{The Physical Conditions and Treatment of Unaccompanied Minors in}

Detention in the United States

"All I think about is when I'm going to be free."126

The treatment of unaccompanied minors in the United States is inconsistent and exposes children to multiple human rights violations while they await their interview with immigration officers. ${ }^{127}$ Unaccompanied minors, who have oftentimes fled violent and traumatic situations, are subjected to punishment and strict rules when they arrive in the United States. ${ }^{128}$ In one detention center in Pennsylvania, a child was forced to do 200 push-ups because he did not pick up a napkin. ${ }^{129}$ When he was unable to complete the punishment due to his lack of physical strength, he was forced to sit at a table with his hands on his head for the remainder of the day. ${ }^{130}$ Other forms of punishment include taking away a child's blankets and mattress as well as adjusting the thermostat to extremely cold temperatures. ${ }^{131}$ According to one child, "The rules mean they can throw people around."132

Guards often physically and verbally abuse the children. ${ }^{133}$ When a child, excited about playing a game, waved his hand and jumped up and down, staff members knocked his head against the wall and kicked him. ${ }^{134}$ "They sometimes hit me with their sticks and shoved me and other boys when they thought we were not following their orders," said one unaccompanied minor in detention. ${ }^{135}$ Another minor, who was punished for trying to watch television, described the physical effects: "As a result of being held like a pig, I was badly injured. I was walking with a big limp."136

126. Seventeen-year-old asylum seeker to Amnesty International delegate after being in detention for ten months quoted in AMNESTY INTERNATIONAL, supra note 3, at 56.

127. Wendy Young, U.S. Detention of Women and Children Asylum Seekers: A Violation of Human Rights, 30 U. MIAMI INTER-AM. L. REV. 577, 597-99 (1999).

128. AMNESTY INTERNATIONAL, supra note 3, at 29.

129. Id.

130. Id.

131. Id at 30.

132. Id. at 29.

133. See Improvements Noted at INS Detention Center Better Guard Training and Oversight Needed, HUMAN RIGHTS WATCH, Oct. 4, 2002, available at http://hrw.org/press/2002/10/san-1004.htm (last visited Mar. 13, 2004). U.N. Rules for the Protection of Juveniles Deprived of Their Liberty allows restraint and force in "exceptional cases, where all other control methods have been exhausted and failed ... in order to prevent the juvenile from inflicting self-injury, injuries to others or serious destruction of property." Protection of Juveniles, supra note 61, at Rule 64.

134. AMNESTY INTERNATIONAL, supra note 3, at 30-31.

135. Id.

136. Id. 
Although it is arguably cruel and unusual punishment for a child, ${ }^{137}$ unaccompanied minors are also punished with solitary confinement for minor infractions such as talking during class. ${ }^{138}$ Solitary confinement and seclusion often result in depression and mental stress for a child, and the results may be even more dramatic for a child who has already experienced great trauma. ${ }^{139}$ Yet, fifty-seven percent of detention facilities for unaccompanied minors report using solitary confinement for punishment. ${ }^{140}$

Unaccompanied minors are routinely held in the same cell as juvenile offenders. ${ }^{141}$ Xaio Ling, a young girl from China, did not speak any English when she was detained by the INS. ${ }^{142}$ Unaware of the reason for her detention, Xaio was placed among children guilty of violent crimes, including rape and murder. ${ }^{143}$ While in detention she was shackled with handcuffs and subjected to frequent strip-searches. ${ }^{144}$ Xaio was not guilty of a crime but was forced to endure a criminal's punishment. ${ }^{145}$ She was even forbidden to laugh, under the policies of the detention center. ${ }^{146}$ Xaio's experience is not uncommon among unaccompanied minors.

Sixty-one percent of facilities regularly strip-search the children in their care, regardless of age or stage of development. ${ }^{147}$ Strip-searches often occur after visits from lawyers: "Every time [my lawyer] visited, they made me take off all my clothes to search my body. This embarrassed me."148 Similarly, although international standards require that restraints only be used in extraordinary circumstances, children are often transported in leg and wrist shackles (even when they are sick and pose no threat) and are forced to wear restraints in court and in detention facilities. ${ }^{149}$

The protection and security of unaccompanied minors in detention are equally suspect. Detained minors are easy and frequent targets for juvenile offenders, who rob, beat up, harass, and attack unaccompanied minors. ${ }^{150}$

137. Protection of Juveniles, supra note 61, at I.2; VAN BUEREN, supra note 35, at 224 (arguing that treatment of an adult that is legal may not be legal as applied to a child; for example, it is cruel to subject a child to solitary confinement).

138. AMNESTY INTERNATIONAL, supra note 3, at 32.

139. Id. at 33.

140. See id. at 32.

141. Id. Forty-eight percent of detention facilities report housing minors in the same cell as juvenile offenders. Id.

142. 121 CONG. REC. S396-398 (daily ed. Jan. 22, 2001) (statement of Mrs. Feinstein). Congressional Record supporting the Unaccompanied Alien Child Protection Act.

143. See id.

144. See id.

145. See id.

146. See id.

147. AMNESTY INTERNATIONAL, supra note 3, at 33-34. Staff in one detention center allegedly referred to the minors as "you little whores" while strip-searching them. Id.

148. Id.

149. Id. at 35. Other forms of restraint include chemicals, like pepper spray. See id. at 37.

150. Navarro, supra note 17 , at 600 . 
Even guards present a threat to an unaccompanied minor's safety: in 1989, an INS guard was convicted of sexually assaulting detained minors in his care. ${ }^{151}$ The situation in the United States is especially urgent because some children are reportedly housed among adult criminal inmates, thereby increasing their risk of harm. ${ }^{152}$ In the United States, one in five men and one in four women is raped in prison. ${ }^{153}$ The victims of rape are usually young and non-violent offenders; the risk for a detained immigrant youth is much greater. ${ }^{154}$ Detention practices like these are physically unsafe for unaccompanied minors. ${ }^{155}$

\section{The Emotional and Mental Effect of Detention for Unaccompanied Minors in the United States}

"Gets pressure. Can't breathe. Like a needle ... It's when I'm thinking." 156

As this section will reveal, detention facilities prove mentally and emotionally traumatizing for unaccompanied minors who are deprived of education and adequate mental health services. Although international and domestic law requires at least primary education for children in detention, twelve percent of facilities provide no education at all. ${ }^{157}$ Those that do provide education do not take into account the language barriers many of the children experience. ${ }^{158}$ English as a second language is only taught in forty-

151. See id citing Lisa Baker, INS Guard Pleads Guilty to Molesting Two Teenagers, BROWNSVILIE HERALD, Aug. 31, 1989, at 1.

152. AMNESTY INTERNATIONAL, supra note 3 , at 27. See also Cate Doty, Teenage African Immigrant is Freed After 3 Years in Detention, N.Y. TIMES, Dec. 25, 2003 at A17. A mentally retarded fifteen-year-old boy was detained with adults when INS declared him to be an adult despite a birth certificate to the contrary. Id. He suffered multiple abuses while in detention. Id. See also Julia Stiles, 1 Had to See for Myself, MARIE ClaIRE, Jan. 2004, at 40. After Fantiz, age sixteen, suffered genital mutilation and other physical abuses in West Africa, she fled to the United States. Id. A dentist incorrectly determined she was eighteen and she was immediately sent to an adult prison where she was detained for over a year. Id.

153. Lara Stemple et al., Doing Something About Prison Rape, HUMAN RIGHTS WATCH, Sept. 26, 2003, available at $\mathrm{http}: / / \mathrm{www} . h r w . o r g /$ ditorials/2003/prison092603.htm (last visited Mar. 13, 2004).

154. See id. The U.S. Congress unanimously passed the Prison Rape Elimination Act of 2003 which authorizes federal grants for programs to prevent and punish prison rape and cuts federal funding for states that do not control sexual abuse of prisoners. Prison Rape: Groundbreaking New U.S. Law, HUM. RTS. WATCH July 2003, at http://www.hrw.org/update/2003/ 07/\#1 (last visited Mar. 13, 2004).

155. Navarro, supra note 17 , at 600 .

156. AMNESTY INTERNATIONAL, supra note 3, at 40 (statement from a child describing an anxiety attack to Amnesty International in 2002).

157. Id. at 39 .

158. Id. at 40 . Forty-eight percent of facilities do not provide education in the child's native language. $I d$. 
three percent of facilities. ${ }^{159}$ What more, religious services are not provided and religious practice is inconsistently facilitated in detention centers. ${ }^{160}$

Children, specifically unaccompanied minors, react to detention facilities by exhibiting signs of depression, mental distress, crying continuously, or becoming listless. ${ }^{161}$ Despite the emotional torment of long-term detention, only thirty percent of detention facilities provide mental counseling or emergency health treatment. ${ }^{162}$ In one case, a child, whose mental health deteriorated significantly when he was placed in detention, began suffering visual and auditory hallucinations. ${ }^{163}$ Although authorities, including the INS, and the facility superintendent, were aware of his condition, the child did not receive treatment or an evaluation of his psychiatric symptoms. ${ }^{164}$ The mental health of this child and others decline when they are forced to remain in detention centers, which predictably exacerbate the mental and emotional trauma already inherent in their unaccompanied immigration. ${ }^{165}$ Guards are not trained to deal with mental illness and often their dealings with traumatized children catalyze greater damage. ${ }^{166}$

\section{The Barriers to Legal Assistance for Unaccompanied Minors in the United States}

"Every child deprived of his or her liberty shall have the right to prompt access to legal and other appropriate assistance."167

Unaccompanied minors are ignorant about U.S. immigration proceedings and are unaware of the rights to which they are entitled. ${ }^{168}$ Yet, they are expected to independently maneuver through deportation proceedings that will determine the legality of their presence in the United States. Deportation

159. Id.

160. AMNESTY INTERNATIONAL, supra note 3, at 43.

161. See id. at 40.

162. See id. at 41.

163. See id. at 42.

164. See id.

165. David A. Martin, Reforming Asylum Adjudication: On Navigating the Coast of Bohemia, 138 U. PA. L. REV. 1247, 1291 (1990); AMNESTY INTERNATIONAL, supra note 3, at 42. See Kristine K. Nogosek, It Takes a World to Raise a Child: A Legal and Public Policy Analysis of American Asylum Legal Standards and Their Impact on Unaccompanied Minor Asylees, 24 HAMLINE L. REV. 1, 10. The lack of consideration of special needs of gender also contributes to the emotional stress associated with detention. Id. Females are rarely given privacy and their facilities are not consistently guarded by females. Id. This places them at greater risk. See id. In one facility a male guard was overseeing the girls' wing. Id. From his control station, he could clearly see the open shower and toilet facilities for the girls. Id. at 44 .

166. See AMNESTY INTERNATIONAL, supra note 3, at 41-42.

167. CRC, supra note 1 , art. 37(d).

168. Navarro, supra note 17, at 602. See also Guidelines on Protection and Care, supra note 61 , at $97-103$. 
proceedings are considered civil matters, as opposed to criminal determinations. ${ }^{169}$ Therefore, unaccompanied minors are not appointed counsel. ${ }^{170}$ Unaccompanied minors who are represented by attorneys are four times more likely to be granted asylum than those who are unrepresented. ${ }^{171}$ If they wish to be assisted by counsel, they are required to obtain a lawyer by their own means. ${ }^{172}$ However, the means available to them are limited; unaccompanied minors are often denied access to telephones during business hours and are thus constructively denied access to potential counsel. ${ }^{173}$ This practice violates the Flores guidelines, which require that children be given a list of pro bono attorneys. ${ }^{174}$ Presenting an additional barrier, it is difficult for attorneys to access the detention facilities, which are typically located in remote areas. ${ }^{175}$ Non-governmental organizations (NGOs) and pro bono attorneys must develop relationships and form agreements with the detention facilities before given access to the children. ${ }^{176}$ In many facilities, NGOs and pro bono attorneys are denied access to the children if they express their views regarding the treatment of unaccompanied minors. ${ }^{177}$

Children are not informed of their rights and often remain in detention facilities, for "weeks [or] months, without such information." 178 Although children have the right to contact their consulate, very few children are made aware of this right and some are denied it. ${ }^{179}$ In one-not uncommon-

169. Nelson v. Immigration and Naturalization Servs. (INS), 232 F.3d 258 (1 st Cir. 2000) (holding that because deportation proceedings are civil proceedings and not criminal proceedings, the Sixth Amendment does not require the appointment of government-provided counsel for the prospective deportees and an alien is afforded the right to counsel at his own expense).

170. See id.

171. AMNESTY INTERNATIONAL, supra note 3, at 61. Less than half of unaccompanied minors in the United States are represented by counsel. See id; WOMEN's COMMISSION, supra note 16, at 6 . "Eighty percent appear in immigration court without the benefit of a lawyer, guardian ad litem, or adult assistance of any kind." Andrew Morton, attorney, Latham \& Watkins, testimony before the U.S. Senate Committee on the Judiciary, Subcommittee on Immigration, Feb. 28, 2002. Another source finds that as few as eleven percent of detainees receive legal assistance. Donald M. Kerwin, Throwing Away the Key: Lifers in INS Custody, 75 INTERPRETER RELEASES 649 (May 11, 1998) quoted in WOMEN's COMMISSION, PROTECTING THE RIGHTS OF CHILDREN: THE NEED FOR U.S. CHILDREN'S ASYLUM GUIDELINES 14 (1998), available at http://www.womenscommission.org/pdf/ins_child.pdf (last visited Mar. 13, 2004).

172. Nelson, 232 F.3d at 260 . The number of children who are actually represented by counsel during immigration proceedings is less than half. WOMEN's COMMISSION, supra note 16 , at 2.

173. Navarro, supra note 17 , at 590. See also AMNESTY INTERNATIONAL, supra note 3, at 44. "[T]he practical implication of this is that the majority of children detained by the INS do not have legal representation." Id.

174. Flores, supra note 90 , at exhibit (2)(J).

175. AMNESTY INTERNATIONAL, supra note 3 , at 45 .

176. See id. at 46.

177. See id.

178. AMNESTY INTERNATIONAL, supra note 3, at 45.

179. See id. at 51-52. 
instance, a child was taken into INS custody and told he had the right to an attorney. ${ }^{180} \mathrm{He}$ was then given papers: "The officers just told me to sign here." 181 The papers waived his right to an attorney and the opportunity to see a judge; the waiver also declared he was willing to voluntarily depart from the United States. $^{182}$

In many cases, unaccompanied and unrepresented minors make incriminating statements to INS authorities when filling out forms. ${ }^{183}$ Board of Immigration Appeals (BIA) board members have based deportation decisions on children's statements to INS officials ${ }^{184}$ despite federal regulations ${ }^{185}$ and Federal Court decisions that the practice was inconsistent with prior rulings. ${ }^{186}$ BIA decisions fail to recognize that a minor, especially under the age of sixteen, lacks "sufficient maturity to appreciate the significance of an interrogation by an INS official and lacks the capacity to evaluate

180. See id at 45 .

181. Id.

182. See id.

183. See generally Terry Coonan, Tolerating No Margin for Error: The Admissibility of Statements by Alien Minors in Deportation Proceedings, 29 TEX. TECH. L. REV. 75 (1998).

184. In re Amaya, Int. Dec. 3293, 1996 WL 507350, 587 (BIA Aug. 23, 1996) (holding that if a judge determines a minor is capable of understanding, then their admissions are acceptable). See also Coonan, supra note 183, at 85, 89-90; In re Ponce-Hernandez, 22 I. \& N. Dec. 784 (May 28, 1999) (holding that there were no grounds for finding that the Form I-213 would be fundamentally unfair although the statements on it were made by an unaccompanied minor and it is not clear that that minor was advised that the form would be used against him); See also Coonan, surpa note 183, at 80 citing In re Hernandez-Jimenez, No. A29-988-097, slip op. at 6 (BIA Nov. 8, 1991) (holding that evidence from INS which was not corroborated and gathered under duress of child was admissible in deportation proceeding - however, all custodial interrogations would be treated as inherently suspect). See Coonan, supra note 183, at 82 citing In re Garcia, No. A70-006-067, slip op. at 3, 5 (BIA Aug. 17, 1993) (finding that the only source of alienage was from an interrogation proceeding in which the minor was unaccompanied; holding that the information, absent a showing otherwise, is regarded as trustworthy and the INS met its burden; however, the submission of a Form I-213 by INS as sole evidence of deportability was insufficient). But see In re Y-C, 23 I. \& N. Dec. 286 (Mar. 11, 2002) (holding that being an unaccompanied minor may constitute a legal disability); Bellotti v. Baird, 443 U.S. 622, 635 (1979) “[D] uring the formative years of childhood . . . minors often lack the experience, perspective, and judgment to recognize and avoid choices that could be detrimental to them." Id.

185. 8 C.F.R. $\S 1240.48$ (b) (2003).

The immigration judge shall not accept an admission of deportability from an unrepresented respondent who is incompetent or under age 16 and is not accompanied by a guardian, relative, or friend; nor from an officer of an institution in which a respondent is an inmate or patient. When, pursuant to this paragraph, the immigration judge may not accept an admission of deportability, Id. he or she shall direct a hearing on the issues.

186. Davila-Bardales v. INS, 27 F.3d 1, 5 (1st Cir. 1994) (holding that a BIA Judge may not base a finding of deportability merely upon a minor's affirmation that the same allegations in a Form I-213 are true). See also Coonan, supra note 183, at 87-88. 
the foreseeable consequences of any responses provided." 187 These are significant barriers for a child that would be surmountable if he or she were provided access to an attorney.

\section{The U.S. Government Perspective}

The purpose of the detention policy is to prevent future illegal immigration and is motivated by an interest in promoting national security. ${ }^{188}$ Opponents to an immigration policy, which would not violate a child's human rights, speculate that alternatives to detention would cause a "magnet effect" for those who are seeking a better life, in addition to those fleeing danger. ${ }^{189}$ It is rationalized that regulation of community safety, and the safety of immigrant minors, takes precedence over the minor's liberty interest and justifies prolonged detention. ${ }^{190}$ Furthermore, it is posited that if the child's release from custody were to result in harm to the child, it would affect international relations and the U.S. government would be liable. ${ }^{191}$ It is reasoned that the detention of a child will eliminate risk of harm because the child will be monitored at all times. ${ }^{192}$ As discussed in Part IV, justifications for the incarceration of unaccompanied minors such as these are artificially cloaked in "the best interests of the child" and should be prohibited. ${ }^{193}$ The U.S. policy of detaining unaccompanied children ${ }^{194}$ completely ignores

187. Coonan, supra note 183, at 77. See also Perez-Funez v. INS, 619 F. Supp. 656, 662 (C.D. Cal. 1985) (holding that voluntary departure procedures as applied to unaccompanied minors violate their due process rights). Unaccompanied children in INS custody encounter a stressful situation in which they are forced to make critical decisions. Their interrogators are foreign and authoritarian. The environment is new and the culture completely different. The law is complex .... In short, it is obvious to the Court that the situation faced by unaccompanied minor aliens is inherently coercive.

Id.

188. Dana Canedy, Hope for Speedy Release of Haitian Refugees Fades, N.Y. TIMES, Dec. 16,2002 , at A18.

189. Susan Martin et al., Temporary Protection: Towards a New Regional and Domestic Framework, 12 GEO. IMMIGR. L.J. 543, 571 (1998); David A. Martin, supra note 165, at 1288.

190. Navarro, supra note 17 , at 605 . Government officials also claimed their efforts to forcibly return Haitians in 1992 to persecution in their country was for the purpose of saving the lives of others who would travel by sea to the United States. Cheryl Little, Beyond/Between Colors: InterGroup Coalitions and Immigration Policies: The Haitian Experience in Florida, 53 U. MIAMI L. REV. 717, 726 (1999).

191. See id.

192. See id.

193. Bhabha, supra note 25 , at 208.

194. See HUMAN RIGHTS WATCH, DETAINED AND DEPRIVED OF RIGHTS: CHILDREN IN THE CUSTODY OF THE U.S. IMMIGRATION AND NATURALIZATION SERVICE, (1998), available at http://www.hrw.org/reports08/ insz (last visited Mar. 13, 2004); C. Nugent, supra note 84; Human Rights Watch, SLIPPING THROUGH tHE CRACKS: UnACCOMPANIED CHILDREN DETAINED BY THE U.S. IMMIGRATION AND NATURALIZATION SERVICE (1997), available at http://www.hrw.org/reports/1997/uscrcks (last visited Mar. 13, 2004). Domestic law requires 
international standards for the "fair and humane treatment of any child in detention."195

B. The Experience of the Unaccompanied Minor Seeking Asylum in Australia

"They were prisoners without having committed any offence.

$\ldots$ Their only fault was they had left their native home and sought to find refuge or a better life on Australian soil." 196

\section{The Physical Conditions and Treatment of Unaccompanied Minors in Australia}

Qamar, a fifteen year old girl from Afghanistan, and her eleven year old brother are orphans detained in Woomera Detention Center. ${ }^{197}$ After their parents were killed by the Taliban, their grandparents paid smugglers to take them to safety. ${ }^{198}$ The last words her grandparents said to the terribly worried Qamar were, "We will try to raise money and follow you, so we can take care of you in Australia." 199 When she and her brother first arrived in Australia, they were interviewed by DIMIA. ${ }^{200}$ Now, every morning, Qamar and her brother dress carefully, waiting to be called for another interview. ${ }^{201}$ At the end of the day in detention, Qamar cries herself to sleep while trying to comfort her brother. ${ }^{202}$

Woomera Detention Center, a former missile base in a remote area where Qamar is detained, is one of the immigration detention centers in Australia. $^{203}$ The Migration Act of 1958 requires that any person, adult or

refugees, victims of torture, and children remain in detention until processed. See Anderson Cooper, African Orphan Fights for Asylum, (CNN POINT television broadcast, Mar. 20, 2002).

195. Bhabha, supra note 25 , at 211.

196. Penelope Debelle, Detention of Migrants Condemned, AGE, Aug. 1, 2002, at 2 (quoting Justice P.N. Bhagwati).

197. Tony Stephens, Bared-wire Playground, SYDNEY MORNING HERALD, Dec. 15, 2001, at 26 (at the time of the article they had been detained for seven months). For additional accounts of unaccompanied minors, see Rebekah Devlin, Centres Cruel to Children, Experts Say, ADVERTISER, Dec. 3, 2001, at 12; Lucy Clark, When We Do Nothing About Child Abuse, DAILy TElEgRAPH, Feb. 8, 2002, at 23; Megan Saunders, Suburban Poverty of Orphan Refugees, AUSTRALIAN, Dec. 17, 2001, at 1.

198. Tony Stephens, supra note 197.

199. Id.

200. Id.

201. Id.

202. Id.

203. Senator Amanda Vanstone, Border Protection: Immigration Detention Centres, at http://www.minister.immi.gov.au/borders/detention (last visited Mar. 13, 2004); Wood, supra note 102 , at 24. 
child, who arrives in Australia be detained until granted a visa or deported. ${ }^{204}$ Children are detained among adults ${ }^{205}$ behind 1200 -volt electric, ${ }^{206}$ barbed wire fences until their cases are reviewed. ${ }^{207}$ Detention may last as long as five-and-a-half years. ${ }^{208}$ When they arrive at a detention center all their belongings are confiscated and they are given a number by which they are identified. $^{209}$ Pursuant to detention center rules, there is a mandatory head count four times a day. ${ }^{210}$

Unaccompanied minors are particularly vulnerable to injury. ${ }^{211}$ While in detention, unaccompanied minors are subjected to a culture of self-harm and suicide; the children have witnessed other people mutilate themselves, start riots, ${ }^{212}$ participate in hunger strikes, ${ }^{213}$ and be subdued by tear gas. ${ }^{214}$ Some unaccompanied children were forced to have their lips sewn together by adult detainees protesting the human rights violations in the detention centers. $^{215}$ Such "actions are extreme, but it's out of a complete sense of desperation and hopelessness." 16

In detention, unaccompanied minors become victims of child abuse, which is "anything individuals, institutions, or processes do, or fail to do,

204. Senator Amanda Vanstone, Frequently Asked Questions, at http://www.minister .immi.gov.au/faq/ detention.htm (last visited Mar. 13, 2004).

205. States to Help Free Detained Children, SYDNEY MORNING HERALD, Dec. 24, 2001 , at 2. This increases a child's risk of physical and sexual assault. Id. The Children Alone Behind the Wire, SYDNEY MORNING HERALD, Nov. 28, 2001, at 1. It is even more likely among unaccompanied minors. See id.

206. Human Rights Watch, By InVITATION ONLY: Australian Asylum Policy 79 (2002), available at www.hrw.org/reports/2002/australia/australia1202.pdf(last visited Oct. 15, 2003).

207. Mia Handshin, No Justice Done to Young and Old Refugees, THE ADVERTISER, Dec. 11,2001 , at 18. Legal team was appalled by the conditions for unaccompanied minors. Id.

208. BY INVITATION ONLY, supra note 206, at 78 .

209. Zachary Steel, Summary Evidence Regarding the Psychological Damage Caused by Long Term Detention, July 3, 2002, at http://www.amnesty.org.au/airesources/docs/refugee/ psychological-damage.doc (last visited Mar. 13, 2004).

210. Michael Millett \& Michael Bradley, Criminals 'Better Off Than Asylum Seekers,' SYDNEY MORNING HERALD, June 7, 2002, at 2.

211. CHILOUT, supra note 108 , at 42.

212. Curtin Riot Highlights Need to Remove Children From Centres, AAP NEWSFEED, Apr. 20, 2002.

213. Russell Skelton, ALP Considers Policy Overhaul on Detainees, AGE, Feb. 15, 2002, at 6.

Minors were removed from Woomera during a hunger strike in 2002 after pressure from community. Id.

214. Ruddock Removes Children, AGE, Jan. 24, 2002, at 1. "This protest is about freedom and basic human rights, it is no longer about visas." Detainees Say Protest is About Human Rights, Not Visas, AAP NEWSFEED, Jan. 20, 2002 (statement from detainees). A group of unaccompanied minors in Woomera threatened to kill themselves en masse if they were not released into foster homes. Conor Lally, 200 Australian Asylum Seekers End Hunger Strike, IRISH TIMES, Jan. 31, 2002.

215. Lally, supra note 214.

216. Ruddock Removes Children, supra note 214. 
which directly or indirectly harms children or damages their prospects of a safe and healthy development into adulthood." 217 Incident reports at the detention centers include allegations of sexual assault. ${ }^{218}$ Multiple incidents of abuse go undocumented or uninvestigated. ${ }^{219}$ For example, a nurse filed a medical report for a twelve-year-old boy she suspected was raped and abused. ${ }^{220}$ Yet, DIMIA reported that no evidence was found to confirm the allegation and no further investigations were needed. ${ }^{221}$

\section{The Emotional and Mental Effect of Detention on Unaccompanied Minors in Australia}

" $[\mathrm{I} \mathrm{m}]$ like a person who is drowning and is holding themselves up by one arm, but my arm is getting tired and it will soon be easier to just let go."222

As a result of detention, "[t]hese children are now completely dysfunctional and we cannot treat them in a detention environment. . . What is happening in Woomera is a medical and psychiatric emergency."223 Over a period of five months in 2001, twenty-nine children harmed themselves physically while in DIMIA detention facilities. ${ }^{224}$ In addition to threats of self-harm, incidents of actual harm include body mutilation, ingestion of shampoo, and attempted suicide. ${ }^{225}$ A psychiatric report found that incarceration in immigration detention centers results in the "widespread psychological and emotional abuse of children and young people" and will have permanent effects on the children's outlook. ${ }^{226}$ Many children become withdrawn, quiet, and difficult to engage and begin to show signs of post-traumatic stress disorder. ${ }^{227}$ Mental health services are ineffective as long as the children

217. National Association for the Prevention of Child Abuse (2002) quoted in CHILOUT, supra note 108 , at iii.

218. CHILOUT, supra note 108, at 11.

219. See id. at 11-12.

220. See id.

221. DIMIA, Response to ChilOut Report "The Heart of the Nation's Existence" (2002), available at http://www.immi.gov.au/detention/chiloutreport_b.htm(last visited Mar. 13, 2004).

222. BY INVITATION ONLY, supra note 206 , at 80 (statement from a fifteen year-old-boy in Villiwood Detention Center on April 6, 2002).

223. Julie Macken, The Face of the Refugee, in Focus, AUSTL. FIN. REv., Dec. 7, 2002, at 25. See also Todd, supra note 25; Schwartz, supra note 26; Totally Amazing Mind, supra note 26; Rebecca Holmes, Child Interns Suffer Social, Mental Trauma, ADVERTISER, July 2, 2002; Penelope Debelle, Children 'Not Protected,' AGE, July 2, 2002, at 6; Suffer the Children, SYDNEY MORNING HERALD, Aug. 1, 2001, at 11.

224. Ruddock Removes Children, supra note 214.

225. See id. See also Devlin, supra note 197.

226. See id.

227. See id. 
remain in detention. ${ }^{228}$ A past staff member at a Woomera detention center cited "a disturbing gap between our international obligations and what is actually happening at Woomera" after witnessing "unlawful child neglect."229

The lack of educational stimulation stunts the child's development and increases the detrimental effects of detention. Children only leave their room to attend one hour of English class four days a week..$^{230}$ One fifteen-year-old boy expressed his concern about the lack of educational facilities. ${ }^{231} \mathrm{He}$ described one class for children of all ages with only one teacher ${ }^{232}$ He said the detention facility is "taking my future along with them because they take my chance of education." 233 The lack of educational stimuli results in dejection for adolescents. ${ }^{234}$ Even if adequate educational opportunities existed, the prolonged, indefinite periods in detention cause depression and reduce the child's motivation to learn. ${ }^{235}$

\section{The Barriers to Legal Assistance for Unaccompanied Minors in Austra- lia}

"We came here to seek refuge, not to be treated like criminals."236

Unaccompanied minors are without judicial ways to challenge their detention. ${ }^{237}$ Despite the findings of the UN Human Rights Committee in $A$ v. Australia that "every detention decision should be open to periodic review so that the justifying grounds can be assessed" and that the absence of this review equates to arbitrary detention, no mechanism for review is in place. ${ }^{238}$ Although the children are not detained in prisons, their experience is even more dangerous because there is less of an accountability framework in the detention centers than in prisons. ${ }^{239} \mathrm{UN}$ officials claimed that criminals were treated better than asylum seekers in Australia. ${ }^{240}$

228. CHILOUT, supra note 108 , at 7 .

229. Ruddock Removes Children, supra note 214.

230. Handshin, supra note 207.

231. BY INVITATION ONLY, supra note 206 , at 80.

232. Id.

233. Id.

234. CHILOUT, supra note 108 , at 24 .

235. See id.

236. Refugee family interviewed by Amnesty International in March 1998 quoted in AMNESTY INTERNATIONAL, A CONTINUING SHAME: THE MANDATORY DETENTION OFASYLUMSEEKERS 19 (1998).

237. Navarro, supra note 17 , at 590. See also AMNESTY INTERNATIONAL, supra note 3, at 44,61 .

238. See A v. Australia, supra note 53. See also Mr. C v. Australia, U.N. Doc. CCPR/C/76/D/900 (1999) (Human Rights Committee, Nov. 5, 2002).

239. BY INVITATION ONLY, supra note 206, at 79.

240. Millet \& Bradley, supra note 210. 
The remote location of facilities serves as a barrier to attorneys and other visitors attempting to contact the children. ${ }^{241}$ Although some unaccompanied minors are informed of their legal rights, the practice is inconsistent and may not occur until the second interview with DIMIA, if at all. ${ }^{242}$ In addition, the government has refused requests by lawyers and other organizations to visit the detention centers and educate recent detainees on their rights. ${ }^{243}$ The Australian government states that the no-contact policy is in sync with its obligation to protect asylum seekers because its goal is to prevent prolonged legal proceedings. ${ }^{244}$

\section{The Australian Government Perspective}

The Australian government denies the human rights watchdogs' reports pertaining to the treatment of unaccompanied minors. ${ }^{245}$ It alleges that the health care in immigration detention centers is even better than the health care most Australian children receive. ${ }^{246}$ The government denies that mandatory detention violates human rights and said that the UN "lacks objectivity and misrepresents important aspects of Australia's management of immigration detention."247 The official rationale of the Australian mandatory detention policy, though admittedly also for deterrent purposes, is to ensure an unlawful non-citizen's availability for processing and removal. ${ }^{248}$ According to the government, outsiders like the UN exacerbate health problems in immigration detention centers. ${ }^{249}$ The Australian government forewarns that any other policy toward illegal immigrants would result in the detainee's disappearance into the country. ${ }^{250}$ In contrast, the UNHCR directs that national security measures should only be implemented when the asylum seeker acts criminally and never as "part of policy to deter future asylum-seekers." 251 The Australian government's attack on the reliability and integrity of human rights bodies, the dismissal of international opinion contrary to its own, and the desire to prevent international human rights law from invading domestic affairs creates an "air

241. BY INVITATION ONLY, supra note 206, at 79.

242. CHILOUT, supra note 108, at 68.

243. A CONTINUING SHAME, supra note 236, at 25-27.

244. See id.

245. Schwartz, supra note 26.

246. Todd, supra note 25. See also Rob Taylor supra note 28; UN Rights Expert Slams Australian Detention of Immigrants, AGENCE FRANCE PRESSE, July 31, 2002.

247. UN Rights Expert, supra note 246.

248. Taylor, supra note 103, at 51; Detention Not Intended as Deterrent-Immigration Official, AAP NEWSFEED, Dec. 2, 2002. See also Mandatory Detention Deters Illegal Immigrants: Australian Official, AGENCE FRANCE PRESSE, Dec. 2, 2002.

249. Millet \& Bradley, supra note 210. Immigration Minister, now Attorney General, Philip Ruddock blames the courts for uncertain lengths of detention saying the issue is "out of my hands." Id.

250. Wood, supra note 102, at 24.

251. Id. 
of Australian inviolability" and a disregard for the well-being of a child seeking asylum, which ultimately results in a breach of international human rights law. ${ }^{252}$

DIMIA faults researchers for blaming the mental health problems of children on their detention experience rather than on the child's experience in their home country prior to arrival in Australia. ${ }^{253}$ The government reports that the immigration detention centers are in good condition: for each unaccompanied minor there are individual management plans, counseling sessions to determine stability, special education comparable to the standard for Australian children, extra-curricular activities, and recreational supplies. ${ }^{254}$ Nevertheless, human rights advocates describe detention centers for an unaccompanied minor as "the anatomy of a death in custody except we're still waiting for the death to take place."255

\section{THE ILLEGALITY OF THE TREATMENT OF UNACCOMPANIED MINORS}

\section{A. The Treatment of Unaccompanied Minors in Australia and the United States Violates International Human Rights Law}

"We just ignore international conventions now, do we?"256

The United States and Australia detain children in harsh and threatening conditions. ${ }^{257}$ Both the United States and Australia regularly deny unaccompanied minors access to counsel, ${ }^{258}$ detain them for prolonged periods of time, ${ }^{259}$ and subject them to prison-like conditions. ${ }^{260}$ These practices violate

252. David Kinley \& Penny Martin, International Human Rights Law at Home: Addressing the Politics of Denial, 26 MELB. U. L. REV. 466, 471, 476 (2002).

253. DIMIA, supra note 221, at Issue 2.

254. David Penberthy, Fair Go for Children Behind the Fences-Officials Provide Different Account-Five Star Asylums, DAILYTELEGRAPH, Dec. 17, 2002, at 4. But see Penelope Debelle, Detention of Migrants Condemned, THE AGE, Aug. 1, 2002, at 2; UN Human Rights Envoy Finds More Humane Approach to Illegal Immigration in Australia 'Would Be Desirable, ' M2 PRESSWIRE, Aug. 1, 2002; Megan Saunders, Woomera Degrades Children: UN Envoy, AUSTRALIAN, Aug. 1, 2002, at 1.

255. Charandev Singh, Human Rights Activist at the Brimbank Community Legal Centre, quoted in Macken, supra note 223.

256. Justice Kirby, during the Australian High Court's hearing of the appeal of Family Court decision that released children in immigration detention quoted in Meaghan Shaw, High Court Invites Child Detention Pleas, AGE, Oct. 1, 2003.

257. See id.

258. See generally Nelson, 232 F.3d 258; A CONTINUING SHAME, supra note 236, at 25.

259. WOMEN's COMMISSION, supra note 16, at 1; FACTSHEET 4, supra note 24.

260. See generally AMNESTY INTERNATIONAL, supra note 3; A CONTINUING SHAME, supra note 236. 
even the minimum standards established by international human rights law. ${ }^{261}$

\section{The Detention of Children}

Arbitrary detention violates multiple international conventions addressing the plight of individuals fleeing from gross human rights violations. Both Australia and the United States are bound by the provisions of the 1951 Refugee Convention. ${ }^{262}$ Article 31.1 of the 1951 Refugee Convention provides that presumed refugees, including children, should not be punished for seeking protection in a state, even if they arrive without the necessary visa or documentation. ${ }^{263}$ Similarly, the ICCPR, which was ratified by the United States in $1992^{264}$ and Australia in $1980,{ }^{265}$ gives everyone the right to freedom from "arbitrary arrest and detention" 266 and forbids "cruel, inhuman or degrading treatment or punishment."267 Policies, such as detention, impose punishment on children and are contrary to the intentions of the 1951 Refugee Convention and the ICCPR. ${ }^{268}$

The U.S. and Australian governments' contention that detention will prevent flight, render the unaccompanied minor accessible for hearing, and deter future migrations does not justify prolonged detention of minors. ${ }^{269}$ Imposing harsh deterrent measures, meant to discourage future applicants from entering the country, results in devastating consequences for children seeking asylum. ${ }^{270}$ In $A v$. Australia, the Human Rights Committee found the detention of a man for ten years to be "arbitrary."271 The case set limits on states and emphasized that detention was an option only when necessary. ${ }^{272}$

261. AMNESTY INTERNATIONAL, supra note 3, at 8. "These children have not committed a crime so punishment by way of incarceration in a detention facility is totally unacceptable." UNICEF, supra note 102.

262. Id. The United States acceded to the 1967 Protocol to the 1951 Convention and amended the Immigration and Nationality Act to conform to the 1967 Protocol. 1967 Protocol, supra note 62, at art. 1, para. 2. See 1951 Refugee Convention, supra note 20.

Id. Australia ratified the 1951 Refugee Convention in 1954 and the 1967 Protocol in 1973. FACTSHEET 11, supra note 36 . The reader should note that in order for international law to become a part of Australian or United States law it must be incorporated into domestic law. See id. Otherwise, neither country is bound by it. See id.

263. Refugee Convention 1951, supra note 20, art. 31.1.

264. AMNESTY INTERNATIONAL, supra note 3, at 9.

265. FACTSHEET 11, supra note 36.

266. ICCPR, supra note 42, art. 9.1. This article expressly apples to Immigration Control. AMNESTY INTERNATIONAL, supra note 3, at 9. Arbitrary has been defined as including "elements of inappropriateness, injustice, and lack of predictability. Id.

267. ICCPR, supra note 42 , art. 7.

268. AMNESTY INTERNATIONAL, supra note 3, at 8; ICCPR, supra 42, art. 9.1, 9.4.

269. Bhabha, supra note 25 , at 208.

270. David A. Martin, supra note 165, at 1291.

271. A v. Australia, supra note 53.

272. See id. See also AMNESTY INTERNATIONAL, supra note 3, at 9. 
In light of the CRC, the governments' justifications for prolonged detention necessarily fail. ${ }^{273}$ Therefore, the United States and Australia shall not deprive a child of "his or her liberty unlawfully or arbitrarily. . . . [D]etention or imprisonment of a child ... shall be used only as a measure of last resort and for the shortest appropriate time."274

\section{Access to Counsel and Judicial Review}

"When we treat these children harshly, they are further traumatized, and our country's credibility as a protector of rights is eroded." 275

The practices in Australia and the United States deny the unaccompanied minor the right "to prompt access to legal and other appropriate assistance, as well as the right to challenge the legality of the deprivation of his or her liberty before a court or other competent, independent and impartial authority, and to a prompt decision on any such action."276 Children must be afforded the opportunity to challenge the deprivation of their liberty; ${ }^{277}$ detention of children must be subjected to periodic judicial review. ${ }^{278}$ Yet, no mechanism for review or challenge is available to children who arrive in Australia without documentation. ${ }^{279}$ The U.S. legal system places significant barriers in front of a child who does not speak English, is developmentally immature, or is too afraid to question his or her predicament. ${ }^{280}$ The childcentered and rights-based approach of the CRC is not applied in these countries. ${ }^{281}$ By denying or impeding attorneys and NGOs access to the children who are unaware of their rights, Australia and the United States constructively deny unaccompanied minors the right to "legal and other appropriate assistance" in contravention of international human rights law. ${ }^{282}$

273. See id. See also FACTSHEET 11, supra note 36.

274. CRC, supra note 1, art. 37(b) (1989). See BY InVITATION ONLY, supra note 206, at 75. See also Protection of Juveniles, supra note 61, Rule 2; Beijing Rules, supra note 59, Rule 179(c).

275. Press Release, First National Survey of Children in Immigration Detention Exposes Mistreatment, Lengthy Detentions, Legal Barriers, AMNESTY INTERNATIONAL, June 18, 2003, available at http://www.amnestyusa.org/news/2003/usa06182003.html (last visited Mar. 13, 2004).

276. CRC, supra note 1 , art. 37(d).

277. See id.

278. FACTSHEET 4, supra note 24 .

279. See id.

280. Coonan, supra note 183.

281. AMNESTY INTERNATIONAL, supra note 3, at 13; CRC, supra note 1.

282. See id. 


\section{Conditions of Detention Facilities}

"This protest is about freedom and basic human rights, it's no longer about visas." 283

The conditions of detention centers and the use of corporeal punishment and solitary confinement by Australian and U.S. officials breach the ICCPR's mandate that " $[\mathrm{n}] \mathrm{o}$ one shall be subjected to torture or to cruel, inhuman or degrading treatment or punishment ..."284 and that "[a]ll persons deprived of their liberty shall be treated with humanity and with respect for the inherent dignity of the human person." 285 In the United States, services available to the unaccompanied minor are insufficient and holding cells are reportedly cold and filthy, with or without bedding. ${ }^{286}$ The secure facilities are intended to hold incarcerated youth offenders. ${ }^{287}$ In Australia, detention centers and facilities are unsanitary, poorly ventilated, and inadequate. ${ }^{288}$ To prevent escape, the detention centers are secure and bordered by barbed wire and highvoltage fences. ${ }^{289}$ These settings are inappropriate for innocent children and are the source of psychological and physical harm because they not only aggravate any previous hardship or torture but create new trauma as well. ${ }^{290}$ This represents a serious breach of the $\mathrm{CRC}$, which recognizes the need to

take all appropriate measures to promote physical and psychological recovery and social reintegration of a child victim of: any form of neglect, exploitation, or abuse; torture or any other form of cruel, inhuman or degrading treatment or punishment; or armed conflicts. Such recovery and reintegration shall take place in an environment which fosters the health, self-respect and dignity of the child. ${ }^{291}$

The conditions of detention centers violate the international standards pertaining to the treatment of children. Rather than fulfill their duty to the

283. Detainees Say Protest is About Human Rights, Not Visas, AAP NEWSFEED, Jan. 20, 2002.

284. ICCPR, supra note 42, art. 7; CRC, supra note 1, art. 37. See also Taylor, supra note 103 , at 55 .

285. ICCPR, supra note 42, art. 10; CRC, supra note 1, art. 37. See also Taylor, supra note 103 , at 55 .

286. AMNESTY INTERNATIONAL, supra note 3, at 20-21.

287. See id.

288. Taylor, supra note 103, at 55.

289. Handshin, supra note 207.

290. BY INVITATION ONLY, supra note 206 at 80. See also Guidelines on Refugee Children, art. 24, UNHCR, U.N. Doc. E/CN 4/28 (1988). "Detention or confinement . . inflict less visible but nevertheless serious psychological and developmental harm on refugee children." Id.

291. CRC, supra note 1 , art. 39. 
children in need of special protection, the U.S. and Australian practices towards the unaccompanied minor create even greater trauma in their defenseless lives.

\section{The Detainment of Children Along with Adults}

I was the youngest one among them and was very scared that the criminal detainees would hurt me. My cell mate had killed someone and would tell me about the crimes he had done. I was so afraid that I couldn't sleep at night ... I felt like my life was finished. I was too young to be there. ${ }^{292}$

Unaccompanied minors in both Australia and the United States report being detained among adults. ${ }^{293}$ This practice places a child in grave danger of sexual and physical abuse. ${ }^{294}$ Children and detention center staff have reported multiple allegations of abuse. ${ }^{295}$ Furthermore, a child's confinement among adults violates the requirements of the CRC, the ICCPR, and the American Convention on Human Rights that children in detention be held separately from adults. ${ }^{296}$ The situation in the United States is especially urgent because some children are housed among adult criminals, increasing their risk of harm. ${ }^{297}$ In Australia, children housed among adult asylum seekers witness adults committing suicide and beginning riots. ${ }^{298}$ The unaccompanied minors, without parents or guardians to protect them, are often forced into protests. ${ }^{299}$ As demonstrated, the failure to provide special measures to separate children from the adults in detention places the children in grave danger and at risk of attack and harm. This practice is in violation of international human rights law. ${ }^{300}$

\section{The Insufficiency of Services}

The lack of services such as educational programs in detention centers in the United States and Australia, deprives children of their rights and is

292. AMNESTY INTERNATIONAL, supra note 3, at 27 (statement of Mekabou Fofana, a sixteen-year-old unaccompanied minor in an U.S. adult criminal detention center).

293. Id.; CHILOUT, supra note 108, at 42.

294. Id.; CHILOUT, supra note 108 , at 42.

295. FACTSHEET 4, supra note 24; Navarro, supra note 17, at 600 ; States to Help Free Detained Children, supra note 205; Children Alone Behind the Wire, supra note 205.

296. ICCPR, supra note 42, art. 10(2)(b); American Convention, supra note 42; CRC, supra note 1, art. 3(1); UDHR, supra note 18, art.5.

297. AMNESTY INTERNATIONAL, supra note 3, at 27.

298. Curtin Riot Highlights, supra note 212; Ruddock Removes Children, supra note 214; Detainees Say Protest is About Human Rights, supra note 214; 200 Australian, supra note 214.

299. Ruddock Removes Children, supra note 214.

300. See CRC, supra note 1, art. 3(1). See also UDHR, supra note 18, art.5. 
inconsistent with international law. ${ }^{301}$ "Everyone has the right to education., ${ }^{302}$ The UDHR, ${ }^{303}$ the UNHCR Guidelines for Refugee Children, ${ }^{304}$ the UN Rules for the Protection of Juveniles Deprived of their Liberty, ${ }^{305}$ and the ICESCR ${ }^{306}$ enumerate the right to education for children. Education is a necessity that ensures the "full development of the human personality and the strengthening of respect for human rights and fundamental freedoms." ${ }^{307}$ Yet, in Australia and the United States, education is sporadic, remedial, and inadequate for unaccompanied minors. ${ }^{308}$ International law requires children be granted at least an elementary education. ${ }^{309}$ This requires accommodations for age, language abilities, and economic status without prejudice. ${ }^{310}$ The Australian and the U.S. educational systems, as it pertains to unaccompanied minors, fail to meet international and domestic standards. ${ }^{311}$

Likewise, the medical services available to unaccompanied minors remain deficient. ${ }^{312}$ The experience of indefinite detention results in extreme emotional, physical, psychological, and mental stress. ${ }^{313}$ Children become easily traumatized by the scenes they witness, the harm they endure, and the conditions to which they are subjected. ${ }^{314}$ Despite the fragile state of these children, the numbers of mental health physicians or counselors are limited

301. Plyler, 457 U.S. 202. In the United States, domestic law also requires refugee children be given a free primary education. $I d$.

302. UDHR, supra note 18, art. 26.

303. See id.

304. Guidelines on Refugee Children, supra note 290, art. 22(1).

305. Protection of Juveniles, supra note 61, Rule 38.

306. ICESCR, supra note 48, art. 13.

307. UDHR, supra note 18, art. 26.

308. AMNESTY INTERNATIONAL, supra note 3, at 40-44; BY INVITATION ONLY, supra note 206, at 80; Macken, supra note 223. See also Todd, supra note 25; Schwartz, supra note 26; Totally Amazing Mind, supra note 26; Holmes, supra note 223; Debelle, supra note 223; Children 'Not Protected,' supra note 223; Suffer the Children, supra note 223.

309. Refugee Convention 1951, supra note 20, art. 22; UNHCR Guidelines on Refugee Children provides that refugee children must be given the same education that national children receive. Guidelines on Refugee Children, supra note 290 , chap. $2, \S 1$.

310. Bhabha, supra note 25 , at 210.

311. See generally Plyer, 457 U.S. 202.

312. AMNESTY INTERNATIONAL, supra note 3, at 40-44; BY INVITATION ONLY, supra note 206, at 90; Macken, supra note 223. See also Todd, supra note 25; Schwartz, supra note 26; Totally Amazing Mind, supra note 26; Holmes, supra note 223; Debelle, supra note 223; Children 'Not Protected,' supra note 223; Suffer the Children, supra note 223.

313. AMNESTY INTERNATIONAL, supra note 3, at 40-44; BY INVITATION ONLY, supra note 206, at 90; Macken, supra note 223. See also Todd, supra note 25; Schwartz, supra note 26; Totally Amazing Mind, supra note 26; Holmes, supra note 223; Debelle, supra note 223; Children 'Not Protected,' supra note 223; Suffer the Children, supra note 223.

314. AMNESTY INTERNATIONAL, supra note 3, at 40-44; BY INVITATION ONLY, supra note 206, at 90; Macken, supra note 223. See also Todd, supra note 25; Schwartz, supra note 26; Totally Amazing Mind, supra note 26; Holmes, supra note 223; Debelle, supra note 223; Children 'Not Protected,' supra note 223; Suffer the Children, supra note 223. 
and incapable of addressing the needs of every child. ${ }^{315}$ International conventions require that action be taken to ensure "physical and psychological recovery."316 The failure to provide counseling and medical services not only violates international obligations, but also increases the irreparable harm done to the children in governmental care. ${ }^{317}$

\section{RECOMMENDATIONS FOR REFORM}

"It is always when the world is undergoing a metamorphosis, when certainties are collapsing, when the lines are becoming blurred, that there is greatest recourse to fundamental reference points, that the quest for ethics becomes more urgent, that the will to achieve self-understanding becomes imperative." ${ }^{318}$

This section lays out recommendations for the treatment of unaccompanied minors which, if incorporated into domestic law, will align Australia and the United States with international human rights law. The recommendations present the ideal practice and might not be immediately achievable in every situation, such as when the minor presents a threat to the safety of self or others, but should be followed as closely as possible and implemented to the best of a nation's ability. To ensure that the rights of the unaccompanied minor are upheld, suggestions for improvement should be incorporated into legislation. ${ }^{319}$

\section{A. Alternatives to Detention}

For the sake of the child's welfare, and in the best interest of the child, unaccompanied minors must immediately be removed from detention facilities..$^{320}$ Detention is only a last resort. ${ }^{321}$ Alternatives to detention include shelters run by NGOs, state welfare organizations, or other child

315. AMNESTY INTERNATIONAL, supra note 3, at 41.

316. CRC, supra note 1 , art. 39.

317. AMNESTY INTERNATIONAL, supra note 3, at 40-44; BY INVITATION ONLY, supra note 206, at 90; Macken, supra note 223. See also Todd, supra note 25; Schwartz, supra note 26; Totally Amazing Mind, supra note 26; Holmes, supra note 223; Debelle, supra note 223; Children 'Not Protected,' supra note 223; Suffer the Children, supra note 223.

318. VAN BUEREN, supra note 35, at 292 quoting Boutros Boutros-Ghali, June 14, 1993, UN Publication DPI/1394/Rev.1/HR, World Conference on Human Rights, at 6.

319. See Kinley \& Martin, supra note 252, at 472 . "International human rights law relies on states for the application and enforcement of human rights norms at the domestic level." Id.

320. Denying the Rights of Asylum Seekers, NEWCASTLE HERALD, Aug. 23, 2001, at 9. See Guidelines on Policies, supra note 56; Guidelines on Protection and Care, supra note 61.

321. CRC, supra note 1 , art. 37(b). 
specialists who will ensure a child's safety. ${ }^{322}$ In multiple instances, relatives or friends of the unaccompanied minor's family are willing and available to act as the guardian for the child pending immigration decisions. ${ }^{323}$ Assessments of available guardians or alternative foster care locations should be expedited to limit the time a child spends in detention. ${ }^{324}$ Where a guardian is unavailable, a foster care system should provide an appropriate place for the child to stay. ${ }^{325}$ To prevent further disruption and trauma in the child's life while in custody, transfers between facilities should only take place if it is in the best interest of the child. ${ }^{326}$ At the very least, detention facilities should be upgraded to meet the international human rights standards. ${ }^{327}$

\section{B. Ensuring Mental and Physical Health}

Children should be treated with respect and dignity by all staff. ${ }^{328}$ The responsible parties should "take all appropriate ... measures to protect the child from all forms of physical or mental violence, injury or abuse, neglect or negligent treatment." ${ }^{329}$ A child should not be restrained with shackles (handcuffs, leg irons, and belly chains) as it is inconsistent with international regulations on the humane treatment of children. ${ }^{330}$ The use of force, chemicals, and other restraint mechanisms should be prohibited. ${ }^{331}$ "Procedures must be in place to ensure that children are not subject to cruel, inhuman, or degrading treatment." 332 Harsh punishments like solitary confinement should be prohibited because the practice's harm to the child is not justified by its disciplinary character. ${ }^{333}$ Violations of a child's body

322. Bhabha, supra note 25 , at 208 . These alternatives could be modeled after the systems in place for children who are at risk of being kidnapped or harm from domestic abuse. See id.

323. AMNESTY INTERNATIONAL, supra note 3, at 53; WOMEN's COMMISSION, supra note 16, at 39; ICCPR, supra note 42 , art. 9.1, 9.4.

324. AMNESTY INTERNATIONAL, supra note 3, at 79. Procedures for assessments should also be reviewed and improved. Id. See also WOMEN's COMMISSION, supra note 16, at 37; CRC, supra note 1, art. 37(b). Protection of Juveniles, supra note 61, Rule 2; Beijing Rules, supra note 59, Rule 179(c).

325. AMNESTY INTERNATIONAL, supra note 3, at 79. This will ensure the "least restrictive setting." Id.

326. See AMNESTY INTERNATIONAL, supra note 3, at 80; ICCPR, supra 42, art. 7.

327. See id. See generally, Protection of Juveniles, supra note 61.

328. See AMNESTY INTERNATIONAL, supra note 3, at 80; ICCPR, supra note 42, art. 7, 10; CRC, supra note 1 , art. 37.

329. CRC, supra note 1 , art. 19; ICCPR, supra note 42 , art. 7.

330. AMNESTY INTERNATIONAL, supra note 3, at 79; Guidelines on Refugee Children, supra note 290 , art. 24.

331. AMNESTY INTERNATIONAL, supra note 3, at 81 . CRC, supra note 1 , art. 24, art. 25 , art. 39; WOMEN's COMMISSION, supra note 16, at 38.

332. AMNESTY INTERNATIONAL, supra note 3, at 81 ; CRC, supra note 1 , art. 24 , art. 25 , art. 39; WOMEN's COMMISSION, supra note 16 , at 38.

333. AMNESTY INTERNATIONAL, supra note 3, at 82. ICCPR, supra note 42, art. 7; CRC, supra note 1, art. 37 . 
through routine pat-downs and strip-searches should be prohibited. ${ }^{334}$ If a staff member engages in prohibited behavior, he or she should be disciplined. ${ }^{335}$

In accordance with international and domestic law, a child should be guaranteed education equivalent to the entitlement of any citizen of the country where the child is detained. ${ }^{336}$ Reading material in the child's own language and other leisurely activities should be made available to the children. ${ }^{337}$ Equally important, children should be provided with regular physical and mental health services. ${ }^{338}$ Detention facility staff should be trained to work with children who have physical and mental disabilities. ${ }^{339}$ These basic health standards could be met with adequate government funding. ${ }^{340}$

\section{Access to Counsel and Child-Centered Immigration Proceedings}

Australia and the United States should revise their immigration systems to ensure that all unaccompanied minors arriving in the country after fleeing persecution receive immediate assistance in maneuvering through the asylum system. ${ }^{341}$ This should include instructions regarding their rights in a language and literacy level the unaccompanied minor will understand. ${ }^{342}$ For this purpose, trained interpreters should be available. ${ }^{343}$ Children should be given immediate access to counsel or the pro bono attorney organizations willing to assist them. ${ }^{344}$ This access should be guaranteed at all stages in their immigration application. ${ }^{345}$ If there are not available NGOs or pro bono attorneys to represent the child, the government should provide legal assistance for the child. $^{346}$

334. AMNESTY INTERNATIONAL, supra note 3, at 82. WOMEN's COMMISSION, supra note 16, at 38. ICCPR, supra note 42, art. 7; CRC, supra note 1, art. 37.

335. AMNESTY INTERNATIONAL, supra note 3, at 81-82.

336. See id. at 82; See generally Plyer, 457 U.S. 202, CRC supra note 1, art. 28(1)(a-b).

337. AMNESTY INTERNATIONAL, supra note 3, at 82. Refugee Convention 1951, supra note 20, art. 22; Guidelines on Refugee Children, supra note 290, chap. 2, § 1 .

338. AMNESTY INTERNATIONAL, supra note 3, at 82 . Female children should be given special attention. Id. Because the number of female unaccompanied minors is less than males, females are more likely to be placed in detention with convicts, where there is available space. Id. See also CRC, supra note 1, art. 39.

339. AMNESTY INTERNATIONAL, supra note 3, at 82; CRC, supra note 1, art. 39, art. 28 (1).

340. AMNESTY INTERNATIONAL, supra note 3, at 82; CRC, supra note 1, art. 39.

341. A CONTINUING SHAME, supra note 236, at 28; CRC, supra note 1, art. 39. UACP, supra note 95.

342. A CONTINUING SHAME, supra note 236 , at 28 ; CRC, supra note 1 , art. 39.

343. AMNESTY INTERNATIONAL, supra note 3 , at 81 .

344. See id. Children should be allowed free telephone calls during working hours to contact attorneys or other advocates. See id. They should be assisted in making these calls. See id. See also CRC, supra note 1. Sharon Finkel, Voice of Justice: Promoting Fairmess Through Appointed Counsel for Immigrant Children, 17 N.Y.L. SCH. J. HUM. RTS. 1105, 1116-19.

345. AMNESTY INTERNATIONAL, supra note 3 , at 13,81 . See generally CRC, supra note 1.

346. AMNESTY INTERNATIONAL, supra note 3 , at 13,81 . 
Immigration proceedings should conform to international law. ${ }^{347}$ Unaccompanied minors should be able to participate fully in proceedings and allowed to appear in person before the judge or asylum officer. ${ }^{348}$ Claims should be processed in a timely manner and hearings held in a language the child will understand. ${ }^{349}$ Any decision to detain a child must be made before a judge during a proceeding in which the child is continually made aware of his or her status. ${ }^{350}$ If a child is detained, he or she should be given the opportunity to appeal the decision. ${ }^{351}$

NGOs and other international human rights organizations should be allowed to train detention center guards and staff, to help improve their skills in treating children and interviewing children. ${ }^{352}$ All employees who have contact with minors, including those of BICE in the United States and DIMIA in Australia, should receive continuing training on the "special needs and rights of unaccompanied minors." 353 For example, regard should be paid to the child's limited knowledge of the political or civil strife or the conditions occurring in his or her country of origin. ${ }^{354}$ Immigration officials responsible for deciding the status of a child's claim for asylum must be trained in interpreting a child's behavior. ${ }^{355}$ Otherwise, a child's hardship in delivering the horror of his or her situation may be mistaken for fabricated stories. ${ }^{356}$ Unaccompanied minors, who are most detrimentally affected by detention, should have an expedited process. ${ }^{357}$

\section{Monitoring and Enforcing Human Rights Provisions}

"[T]he people of the United Nations have . . . re-affirmed their faith in fundamental human rights and in the dignity and worth of the human person, and have determined to promote

347. See id. at 83. "Anyone who is deprived of his liberty by arrest or detention shall be entitled to take proceedings before a court, in order that that court may decide without delay on the lawfulness of his detention and order his release if the detention is not lawful." ICCPR, supra note 42 , art. 9(4)

348. CRC, supra note 1, art. 37(d), 9(4).

349. CRC, supra note 1 , art. 37(d).

350. AMNESTY INTERNATIONAL, supra note 3, at 83.

351. AMNESTY INTERNATIONAL, supra note 3, at 83; FACTSHEET 4, supra note 24.

352. See id. Interviewing children in asylum cases is crucial in ascertaining the facts relevant to their claim. Peter Margulies, Children, Parents, and Asylum, 15 GEO. IMMIGR. L. J. 289, 309.

353. AMNESTY INTERNATIONAL, supra note 3, at 78.

354. Bhabha, supra note 25 , at 218.

355. Id.

356. Taylor, supra note 103 , at $86-91$.

357. AMNESTY INTERNATIONAL, supra note 3, at 83; CRC, supra note 1, art. 37(b) (1989). See By INVITATION ONLY, supra note 206, at 78. See also Protection of Juveniles, supra note 61, Rule 2; Beijing Rules, supra note 59, Rule 179(c). 
social progress and better standards of life in larger freedom."358

There must be a confidential mechanism in place for lodging complaints and violations of liberty. Without an effective way of monitoring authority figures and the mistreatment of unaccompanied minors and other immigrants, a risk exists that the most inexpensive method of administration will be relied upon while sacrificing the child's well-being. ${ }^{359}$ All allegations of abuse should be thoroughly and independently investigated by an agency focused on the best interests of the child. ${ }^{360}$

Data collection should be given significant attention to ensure improvement in the treatment of current and future unaccompanied minors. ${ }^{361}$ The informational file for each minor should detail any and all contact with NGOs, attorneys, and other advocates as well as the child's progress through the immigration system. ${ }^{362}$ Information about the characteristics of unaccompanied minors and other asylum seekers (such as age, nationality and gender) as well as any policy changes should be made publicly available, subject to the right to privacy. ${ }^{363}$

\section{E. Suggestions for Reform Specific to the United States}

"The United States must acknowledge and uphold the rights and needs of newcomer children in order to live up to its reputation as a leader in human rights and a nation that protects its children." ${ }^{364}$

The U.S. government should immediately ratify the Unaccompanied Alien Child Protection Act of 2003 and the UN Conventions on the Rights of the Child. ${ }^{365}$ The United States should also implement the provisions of Flores. ${ }^{366}$ By codifying these documents, the United States will ensure that children are not housed in detention centers. ${ }^{367}$ In accordance with these

358. Declaration, supra note 2.

359. Taylor, supra note 103, at 58 (describing the bonus and demerit system in Australian detention centers which allows contractors to remain profitable without improving performance).

360. FACTSHEET 4, supra note 24.

361. AMNESTY INTERNATIONAL, supra note 3, at 83.

362. See id.

363. See id.

364. WOMEN's COMMISSION, supra note 16 , at 3 .

365. AMNESTY INTERNATIONAL, supra note 3, at 77. WOMEN's COMMISSION, supra note 16, at 40; UACP, supra note 95; CRC, supra note 1.

366. See AMNESTY INTERNATIONAL, supra note 3, at 79; Flores, supra note 91.

367. See AMNESTY INTERNATIONAL, supra note 3, at 79; ICCPR, supra note 42, art. 9.1 , 9.4 . 
documents, unaccompanied minors should be separated from juvenile offenders and adults in circumstances where no alternatives to detention centers exist. ${ }^{368}$

The United States must establish more accurate age determination procedures. ${ }^{369}$ In the event the procedure is unreliable, the child must be given leniency. ${ }^{370}$ The age determination procedures should conform to the standards of the UNHCR Guidelines on Policy and Procedures in dealing with Unaccompanied Children Seeking Asylum. ${ }^{371}$ In addition, the unaccompanied minor's statements to officials should not be used against him or her. ${ }^{372}$ The burden of proving the deportability of a child should be left to the official. ${ }^{373}$ This will help to ensure that no child is returned to a country where his or her life will be in jeopardy. ${ }^{374}$

The U.S. government should ensure that the ORR is adequately funded and supported in carrying out proposed improvements. ${ }^{375}$ The government should seek the assistance of international human rights groups and watchdogs and invite them to evaluate the current system and propose changes. ${ }^{376}$ The UN Working Group on Arbitrary Detention should be included as an evaluator. ${ }^{377}$ "The unique dilemma of the alien minor raises a claim for legal protection that must be more humanely and consistently addressed by U.S. immigration law." ${ }^{378}$ Should the United States reform its policy towards unaccompanied minors, multiple organizations within the country will support the change. ${ }^{379}$

368. See AMNESTY INTERNATIONAL, supra note 3, at 79; CRC, supra note 1, art. 3(1); UDHR, supra note 18, art. 5; ICCPR, supra note 42.

369. Bhabha, supra note 25 , at 218.

370. AMNESTY INTERNATIONAL, supra note 3, at 78 . In the event age can not be determined, rather than placing the child with adults a separate facility should be designated for the unaccompanied people who may be minors. See id.

371. Id; Guidelines on Policies, supra note 56; WOMEN's COMMISSION, supra note 171, at 14-16.

372. Coonan, supra note 183 , at $89-90$.

373. See id. Establish a rebuttable presumption to enhance judicial efficiency. $l d$.

374. AMNESTY INTERNATIONAL, supra note 3, at 78.

375. See id. UDHR, supra note 18, art. 14.

376. AMNESTY INTERNATIONAL, supra note 3, at 78

377. See id.

378. Coonan, supra note 183 , at 96.

379. 8 Members of Congress Urge Release of Immigrant, N.Y. TIMES, Aug. 23, 2003, at A9 (Congressional Human Rights Caucus called for the release of immigrants from prison); African Orphan Fights for Asylum, supra note 194; Catholic Bishop asks the United States to protect refugees globally, especially unaccompanied minors and other vulnerable groups. Prepared Testimony of Nicholas A. Dimarzio, supra note 125. 


\section{F. Suggestions for Reform Specific to Australia}

"To make this Commonwealth of ours renowned of all the lands; for those who've come across the seas we've boundless plains to share; with courage let us all combine to Advance Australia Fair." 380

Although Australia has ratified international human rights treaties, including the CRC, it has not followed them. ${ }^{381}$ Though presented with alternatives to detention on multiple occasions, Australia has been unwilling to implement them. ${ }^{382}$ This shows detention is not a measure of "last resort." 383 The government dismisses alternatives to detention as invitations for large numbers of asylum seekers to disappear into the community and result in a high absconding rate. ${ }^{384}$ "[F]ar from being the only Western country to detain unauthorized arrivals, Australia is providing the model that other countries are seeking to follow," opined the Immigration Minister. ${ }^{385}$ The government's air of imperviousness and conflicting roles of both the guardian of unaccompanied minors and the entity responsible for deporting them must be repaired. ${ }^{386}$

Australia should repeal the mandatory detention policy of unaccompanied minors and revise its relevant laws and regulations that allow the existence of a system so detrimental to unaccompanied minors. ${ }^{387}$ Representatives from the government, the UNHCR, NGOs, and HREOC should be invited to assist in revisions to ensure their conformity to international human rights law. ${ }^{388}$

380. Peter Dodds McCormick, Australian National Anthem (1878) available at http://www.dfat.gov.au/facts/nat_anthem.html (last visited Mar. 13, 2004).

381. FACTSHEET 11, supra note 36. In 1949, Australia initiated the UN Human Rights Commission's adoption of a prohibition against the "arbitrary arrest or detention" of a person, which is found in article nine of the draft International Convention on Civil and Political Rights (ICCPR).

382. BY INVITATION ONLY, supra note 206, at 77. Alternatives to detention have been presented to the Australian government by the Justice for Asylum Seekers (model designates a case worker to oversee asylum seekers and act as an intermediary), Human Rights and Equal Opportunity Commission, Refugee Council of Australia, Human Rights Watch (parole arrangements and release into community), Refugee Action Collective (detention standard that meets international standards or an absolute no-detention standard). Id.

383. CRC, supra note 1, art. 37(b); BY INVITATION ONLY, supra note 207, at 78.

384. AMNESTY INTERNATIONAL AUSTRALIA, FACTSHEET 3: ALTERNATIVES TO DETENTION, available at http://www.amnesty.org.au/refugees/ref-fact03.html (last visited Mar. 13, 2004).

385. Id.

386. Taylor, supra note 103 , at $86-91$.

387. A CONTINUING SHAME, supra note 236 , at 28 ; Refugee Convention 1951 , supra note 20 , art. 31(2); Wood, supra note 102, at 23-4.

388. A CONTINUING SHAME, supra note 236, at 28 ; Refugee Convention 1951, supra note 20 , art. 31(2); Wood, supra note 102, at 23-4. 


\section{CONCLUSION}

The children of the world are innocent, vulnerable and dependent. They are also curious, active and full of hope. Their time should be one of joy and peace, of playing, learning and growing. Their future should be shaped in harmony and co-operation. Their lives should mature, as they broaden their perspectives and gain new experiences.... We ourselves hereby make a solemn commitment to give high priority to the rights of children, to their survival and to their protection and development. This will also ensure the well-being of all societies. ${ }^{389}$

An analysis of the treatment of unaccompanied minors in Australia and the United States reveals that the current policy and practice pertaining to unaccompanied minors in these countries ignore the best interests of children and violate their basic human rights. Australia and the United States are bound by international human rights law, yet their treatment of the most vulnerable of asylum seekers places the mere potential for a national security breach before commitment to children's well-being.

Multiple problems surrounding unaccompanied minors remain unresolved in U.S. and Australian asylum law. ${ }^{390}$ To place a child seeking asylum in a detention center where he or she rarely sees the sun, has few educational opportunities, and feels threatened and fearful, qualifies as cruelty. To subject an unwitting child to corporal punishment for innocent behavior, frequent violations of his or her body through strip searches, and a culture of self-harm among adults and criminal offenders qualifies as inhumane. The treatment of the unaccompanied minors and the attitude of governments that allow it represent a disregard for the human rights of the unaccompanied minors and both must be adjusted to end human rights violations of children in Australia and the United States. ${ }^{391}$

There are significant gaps in the legal and social responsibility for decisions affecting unaccompanied minors in the United States and

389. World Declaration on the Survival, Protection and Development of Children, World Summit for Children, Annex 2, para. 23, at art. 2, 19, U.N. Doc. E/CN.4/1991/59 (1990).

390. See Bhabha, supra note 25 , at 218 . Problems include

measures to address the absence of adequate legal representation or guardianship arrangements; unreliable or harmful age determination procedures; the protracted and often inconclusive nature of legal proceedings to secure permanent legal status; the abusive use of detention, including in some cases punitive measures; the vulnerabilities arising out of smuggling and trafficking arrangements, and the failure to promote family reunification in the receiving or home country. 
Australia. ${ }^{392}$ To meet the requirements of international human rights law, the United States and Australia should reform their detention laws. ${ }^{393}$ Namely, the United States and Australia should immediately end the detention of unaccompanied minors. Under international law the detention of asylum seekers is only allowed as a last resort and should not be routine or for prolonged periods. ${ }^{394}$ These children have not committed any crime and deserve refuge from the harm inflicted upon them in their own countries. Their non-citizenship and illegal entry into Australian and the United States do not justify the harsh treatment they receive.

The United States and Australia must take immediate measures to reform their treatment of unaccompanied minors. Children, regardless of their citizenship or origin, deserve the best humankind has to offer. ${ }^{395}$ To ensure the future welfare of society, children should be given no less. 